\title{
مفهوم المغايرة عند سيبويه
}

\author{
م.م. أمجد ستارساجت علي الحسيني
}

وزارة التربية / مديرية تربية الرصافة الثانية

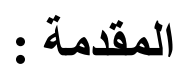

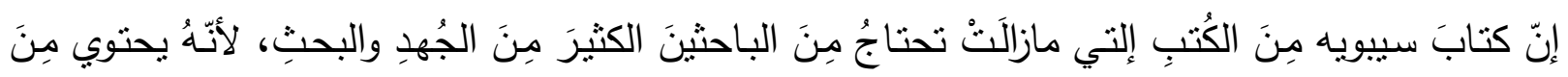

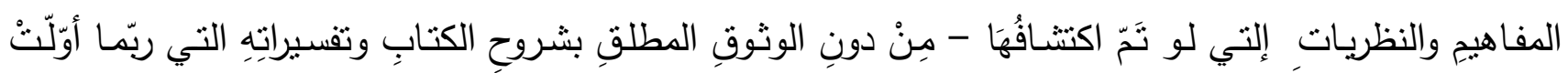

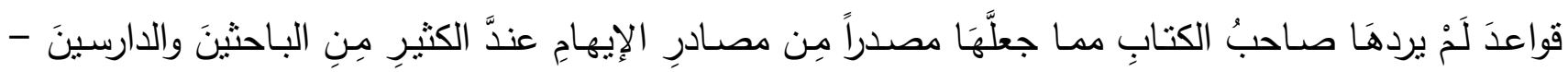

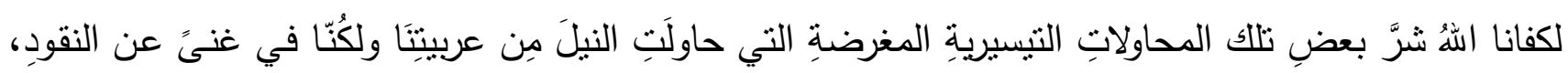

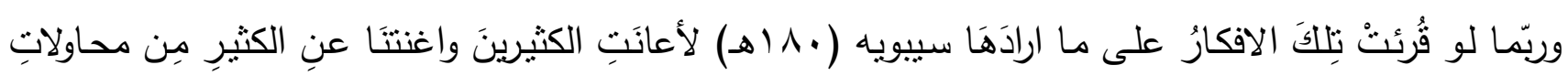

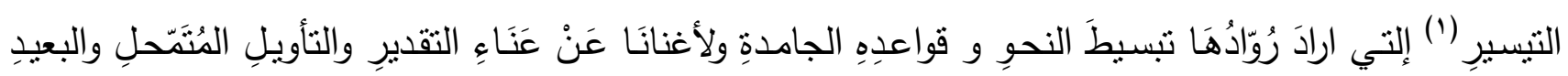

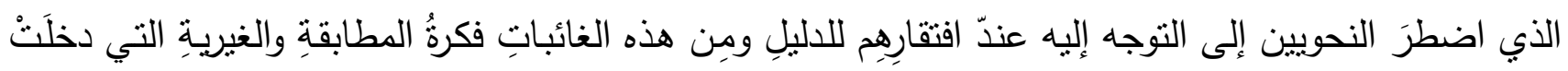

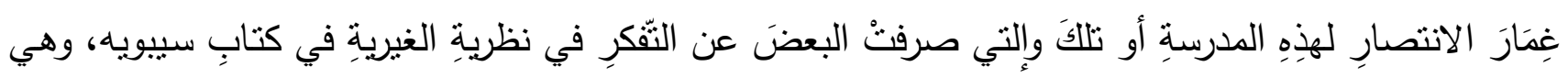

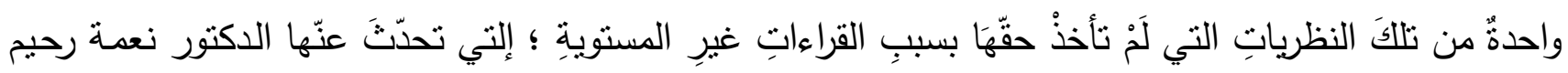

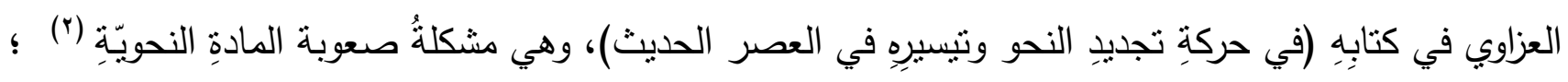

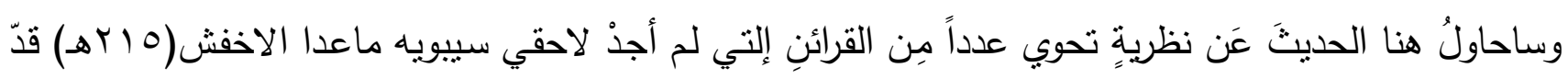

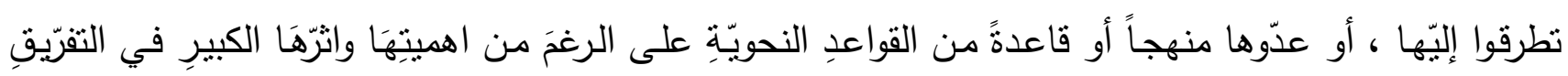

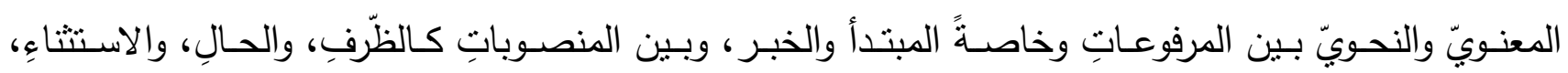

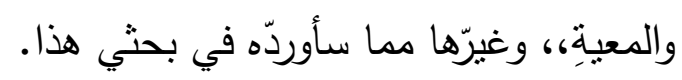




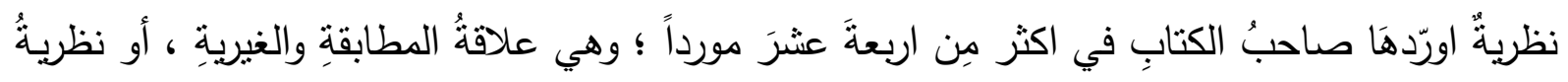

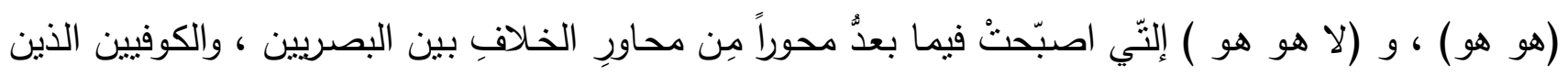

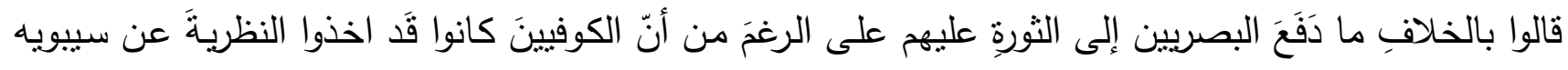

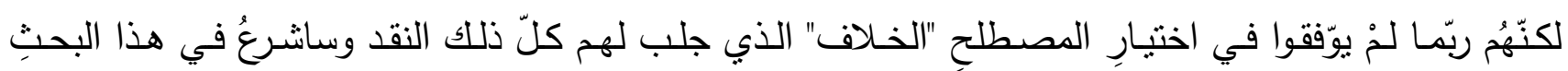

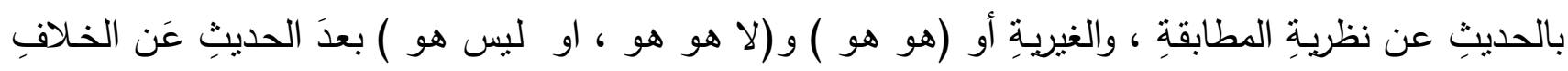

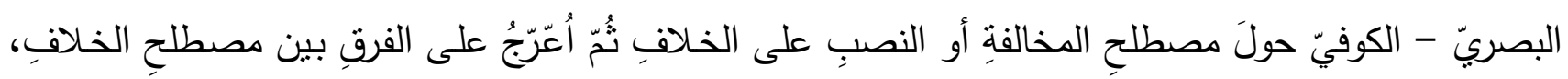

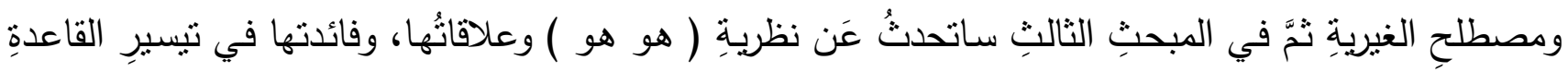

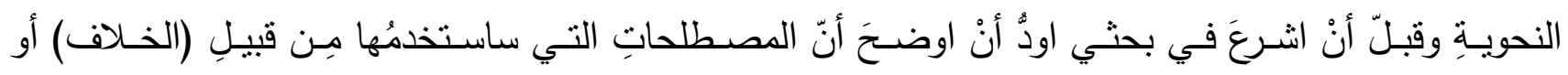

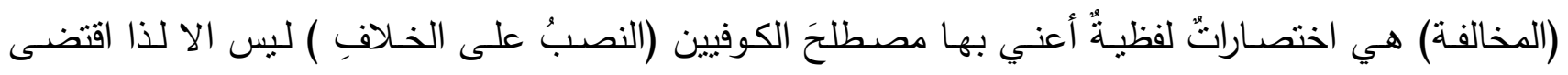
التتويه. - الن

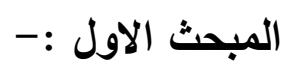

\section{الخلاف بين البصريين والكوفيين في عامل النصب:-}

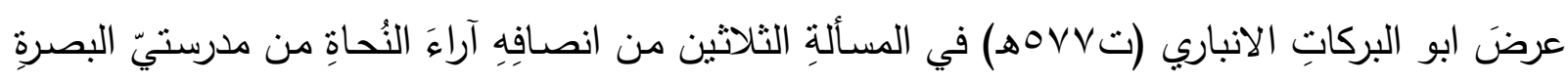

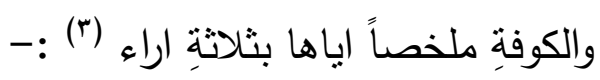

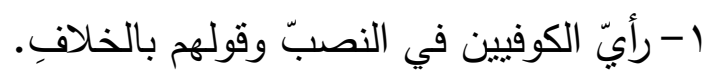

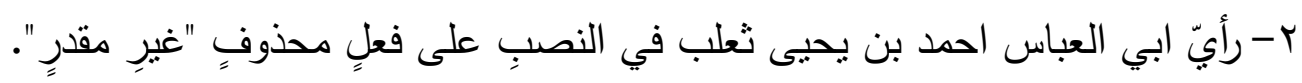

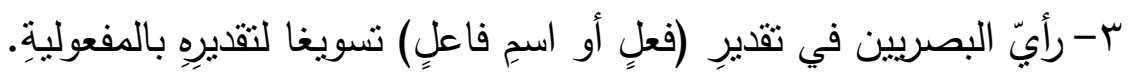

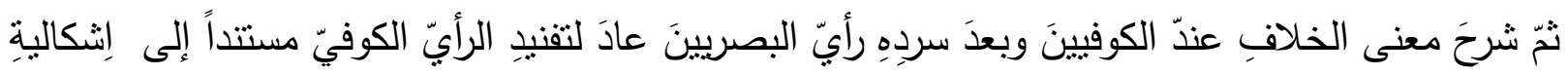

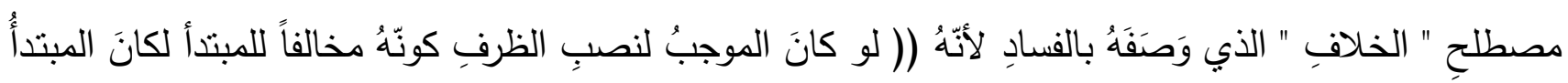

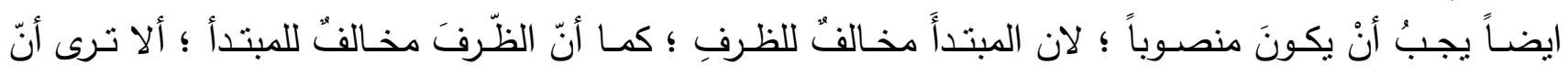

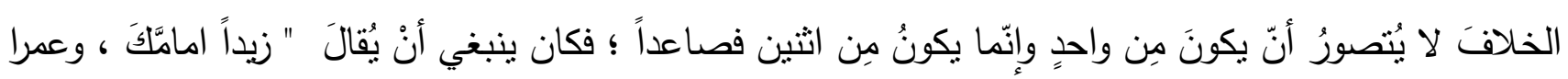

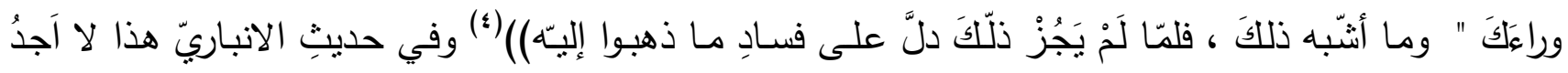

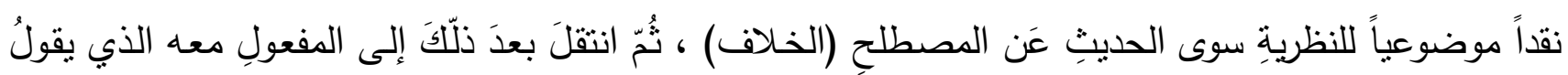




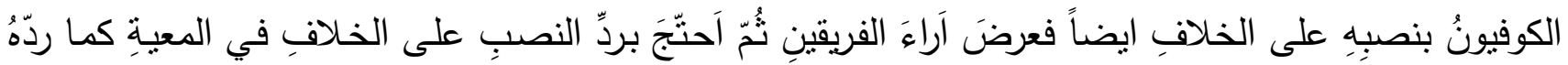

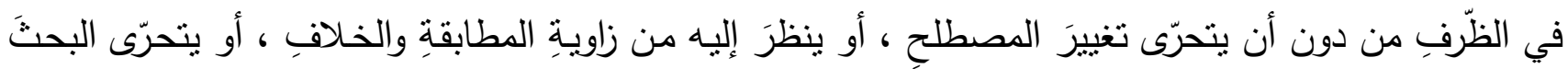

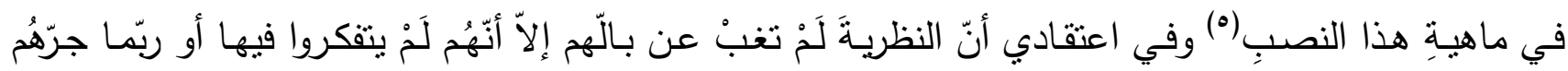

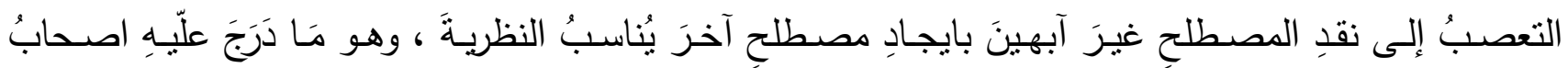

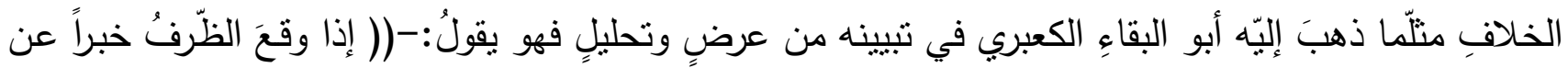

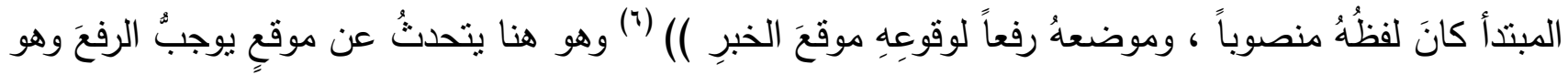

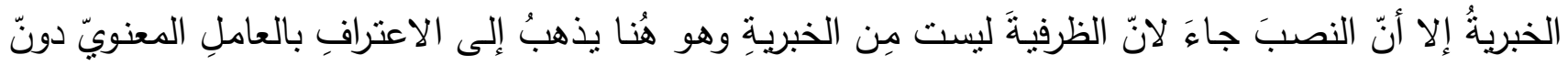

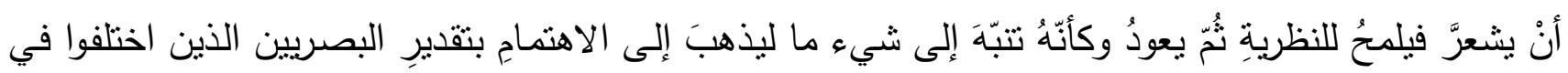

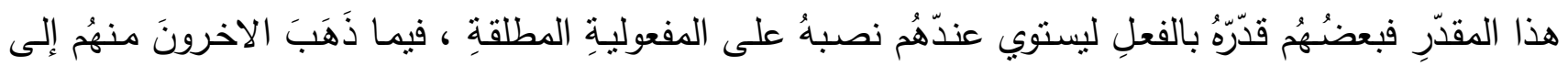

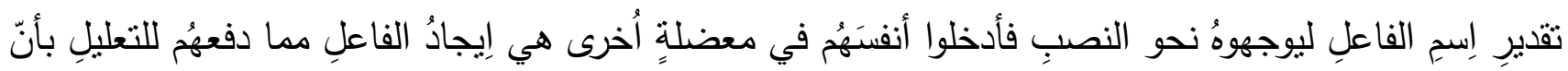

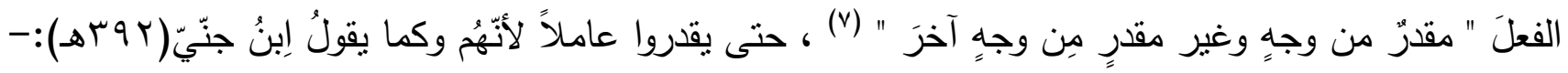

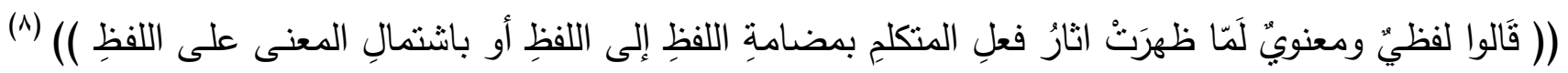

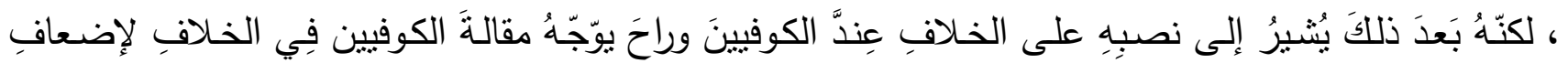

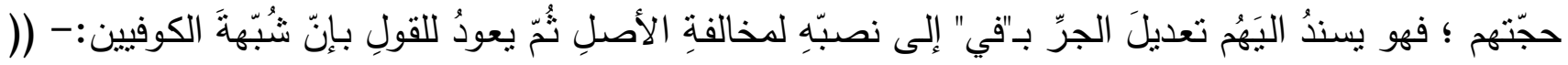

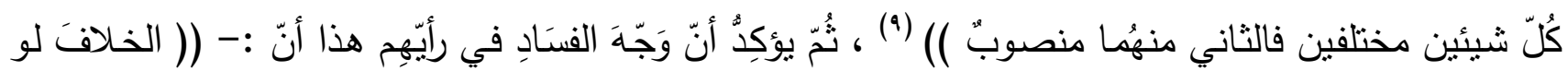

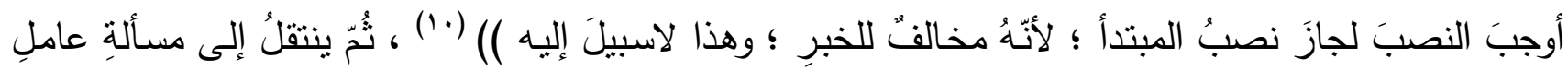

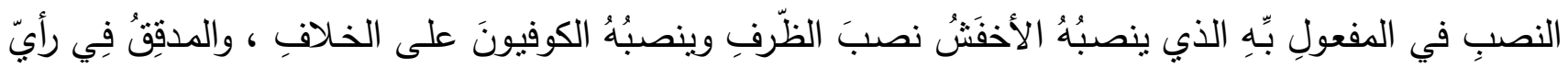

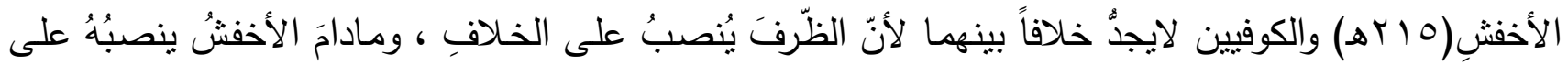

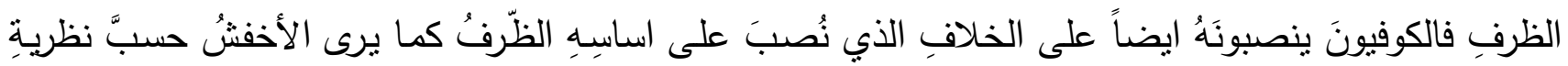

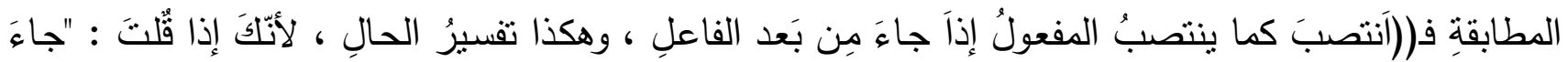

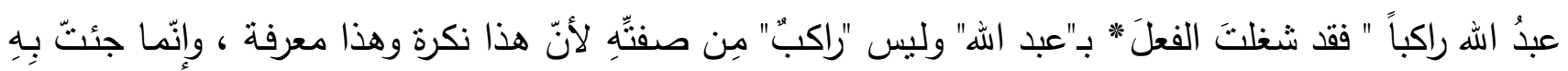

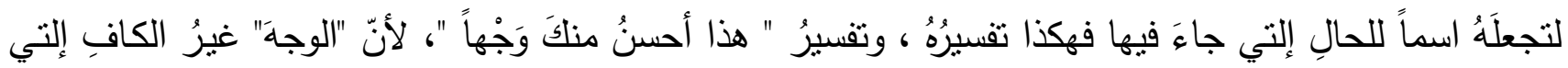

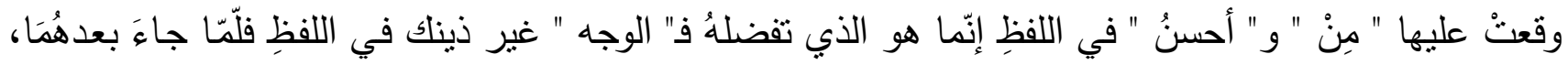




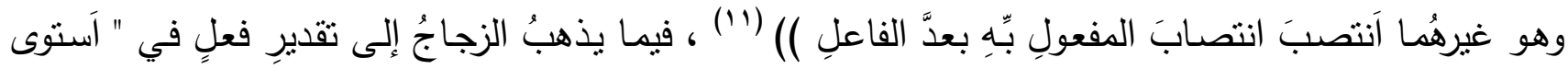

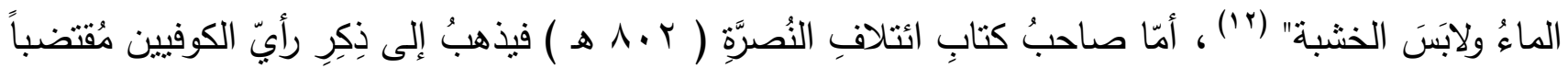

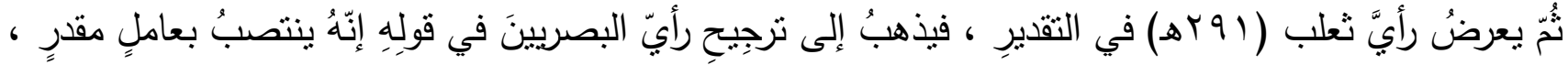
أما فعلٌ أو اسُّ فاعلٍ على اختلافِ التقديرِ ، لأنّ الظّرفَ كلّ ظرفٍ زمانيٍٍ أو مكانيّ فإن فيه معنى (في) و (في)

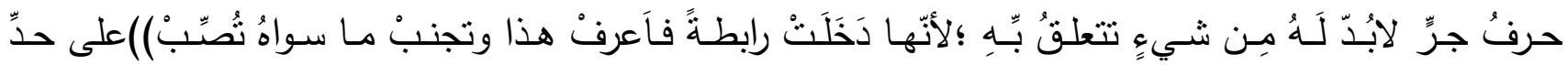

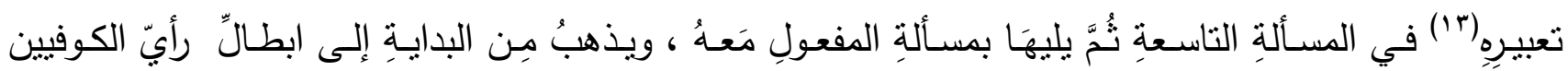

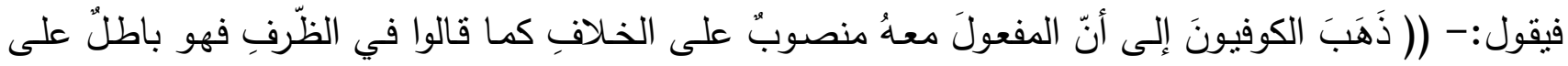

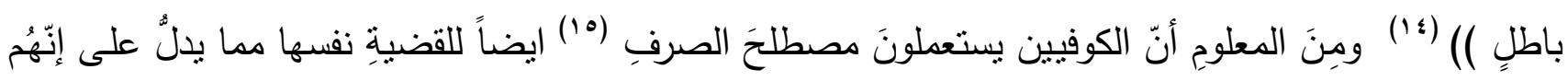
ربّما لَمْ يكونوا مقتتعينَ بمصطلحِهم الاول ، وَعَلِيّ أن اعترفَ أنّ اصحابَ كُتبِ الاختلافِ النحوي كانوا بلامسونَ

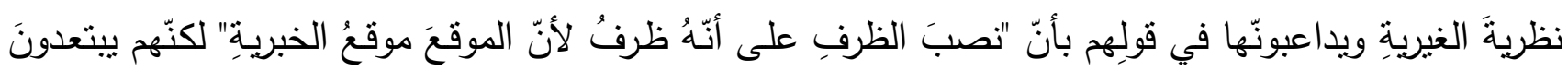
مرةً اخرى عندّما يجنحونَ للتقديرِ • المبحث الثاني :- المرن

\section{الفرق المعجمي بين غير وخلف :-}

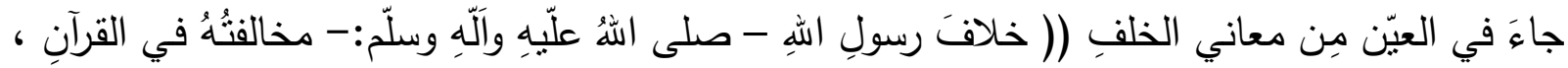

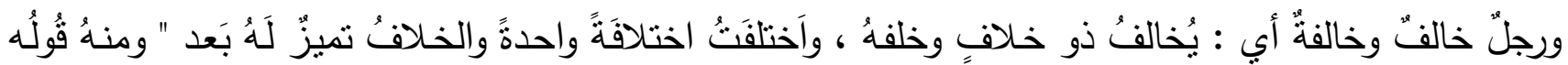

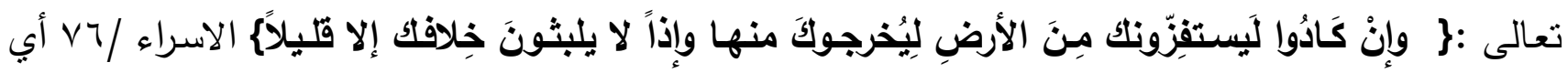

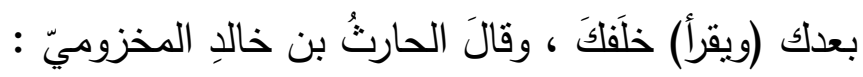

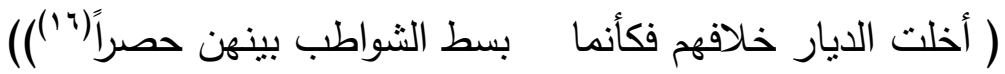
ولَمْ يبتعذْ صاحبُ القاموسِ المحيطِ عَن هذا الرأيّ فقد قالَ (( الخلفُ نقيضُ قداحِ ، والقرنُ بعدَ القرنِ ، ومنهُ ؛ هؤلاءِ خلفُ سوء ... والخلفةُ بالكسرِ ؛ الأسمُ في الاختلافِ ، أو مصدرُ الأختلافِ ، أيّ :هذا خلفهُ مِن هذا ،

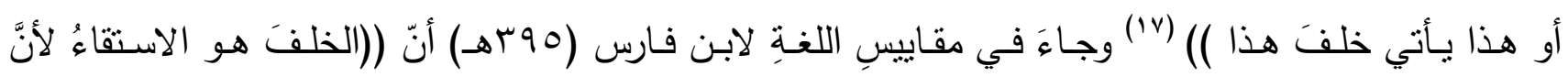

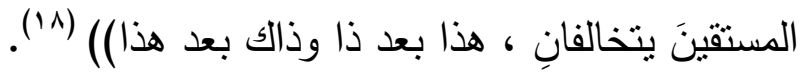




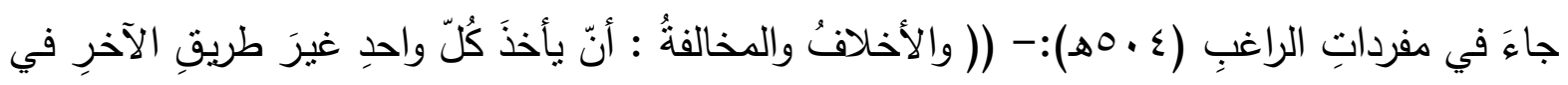

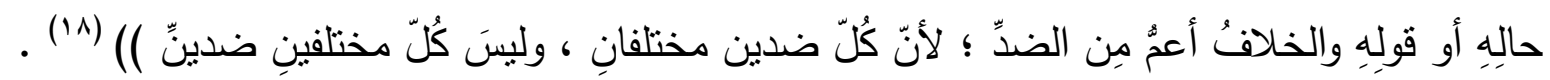

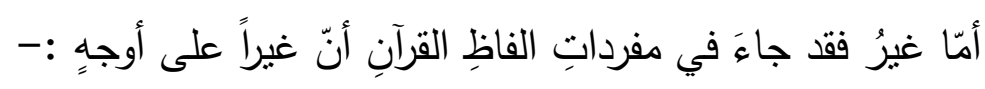

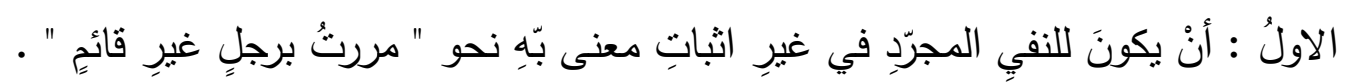

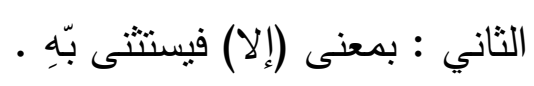

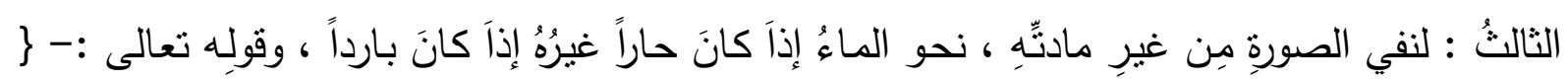

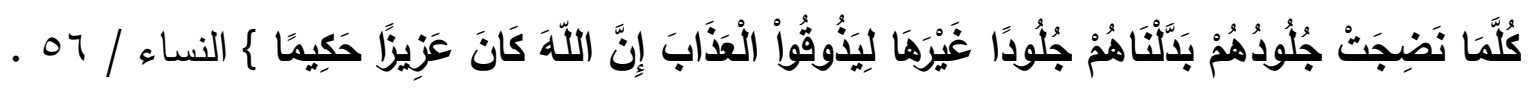

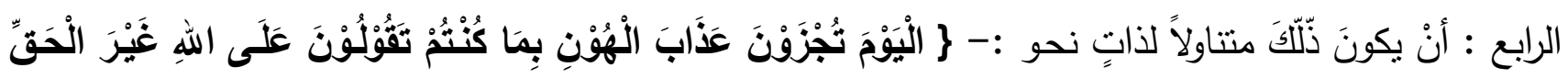

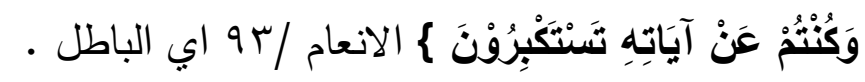

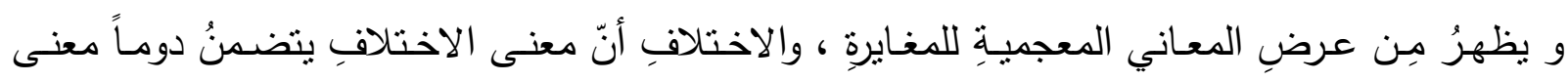

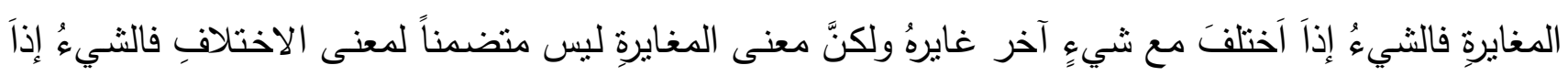

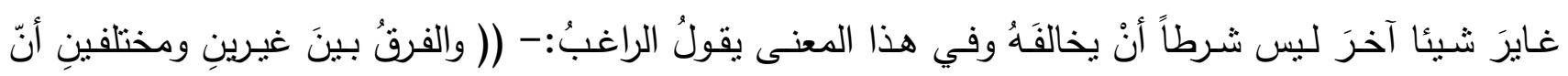

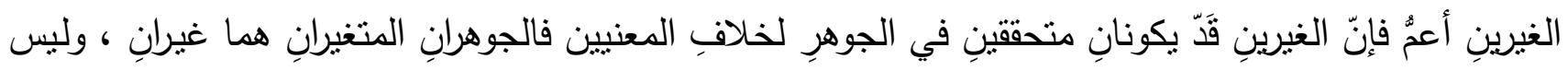

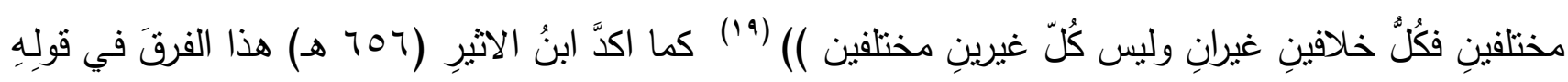

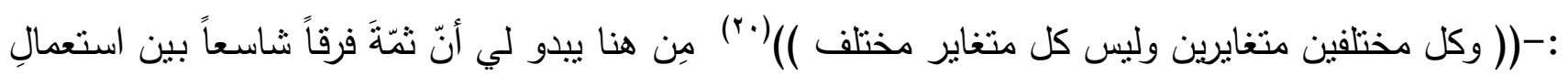

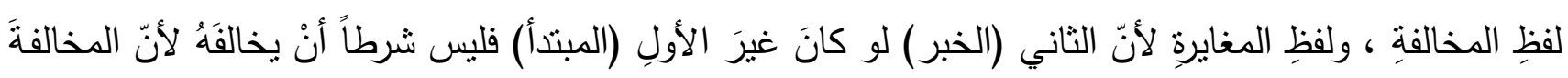

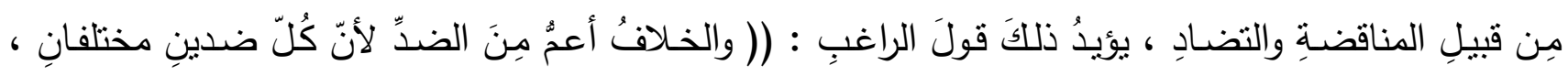

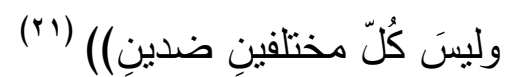

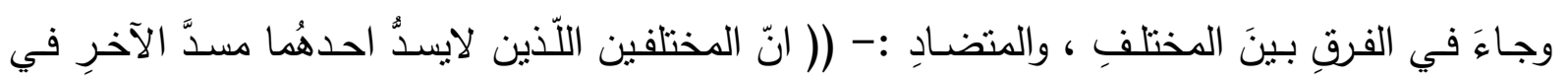

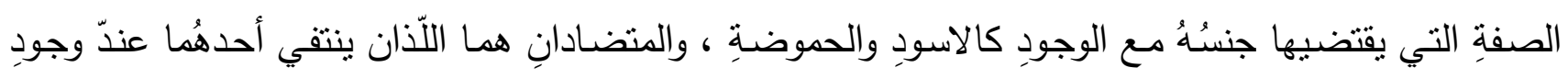

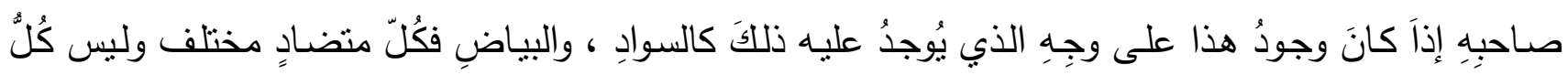

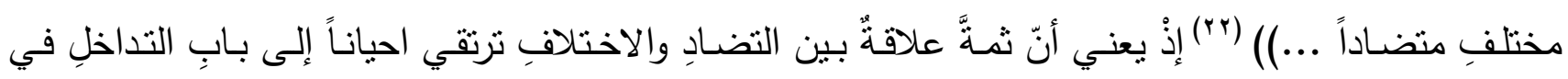




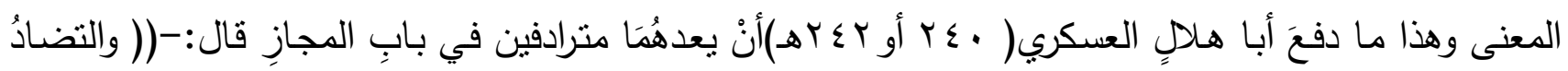

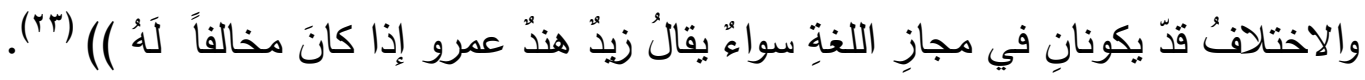

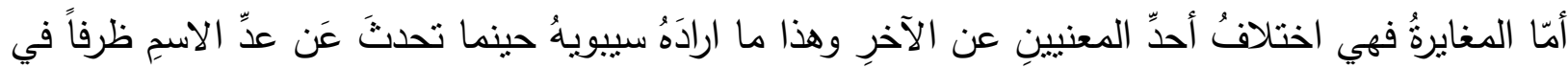

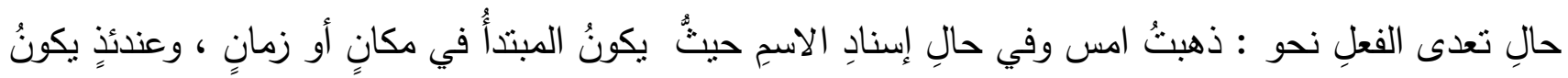

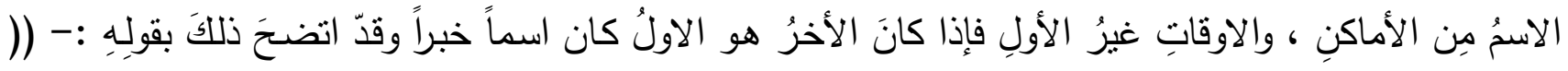

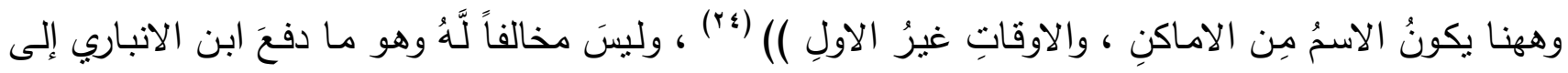

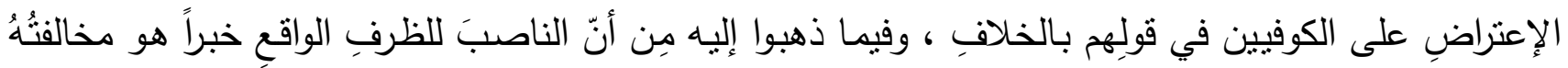

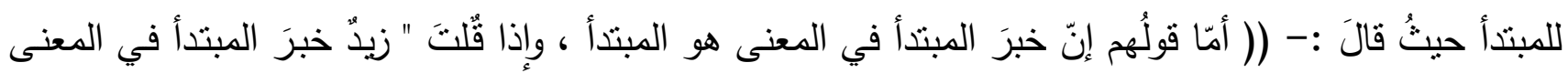

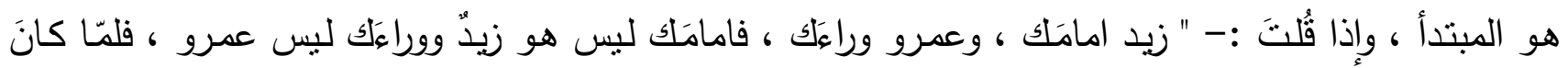

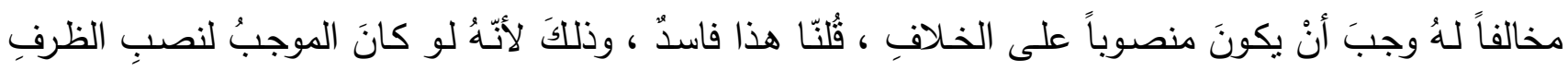

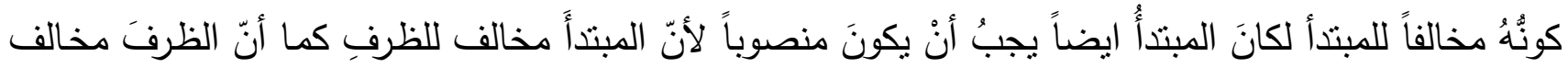

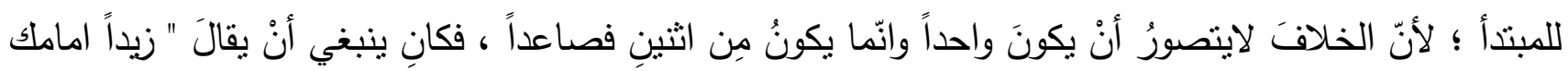

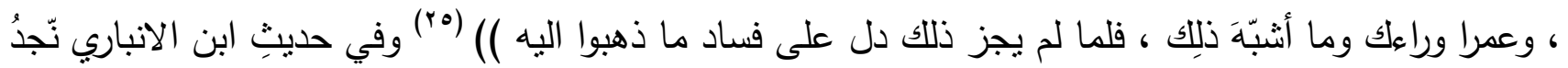

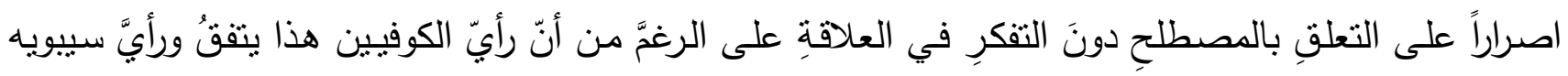

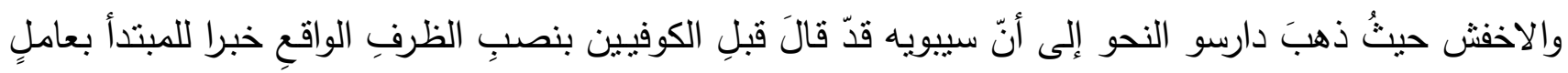

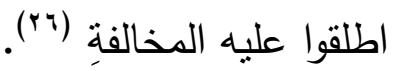

المبحث الثالث

\section{نظرية المطابقة والغيرية :-}

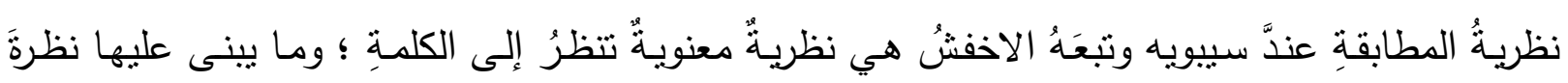

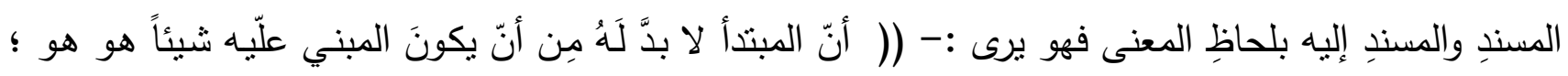

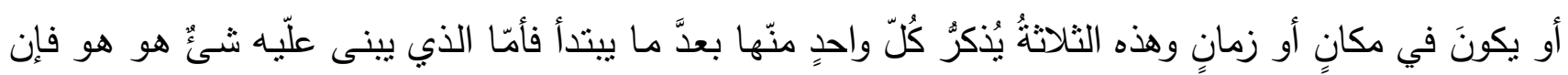

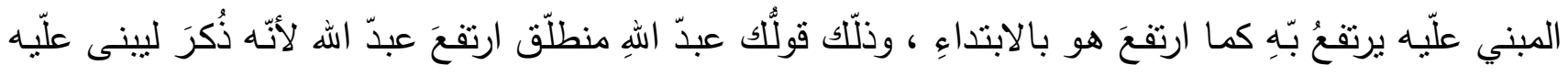

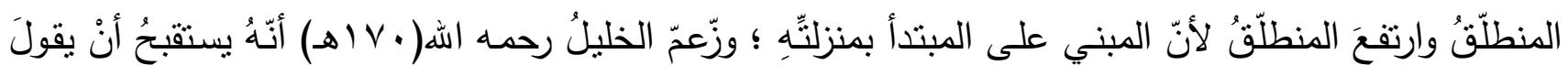




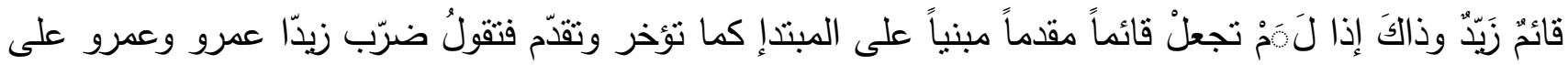

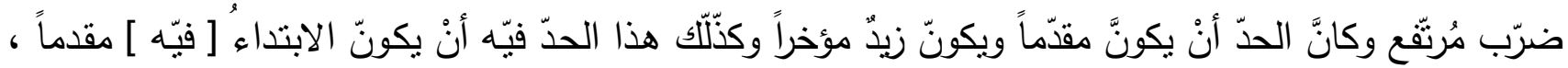

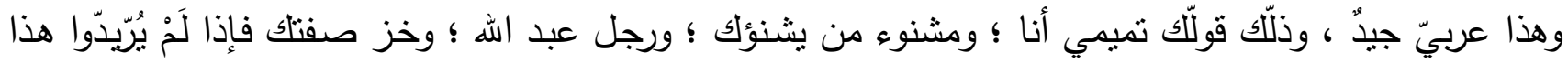

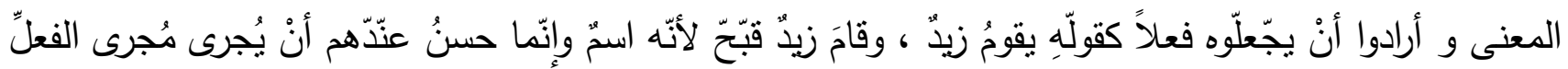

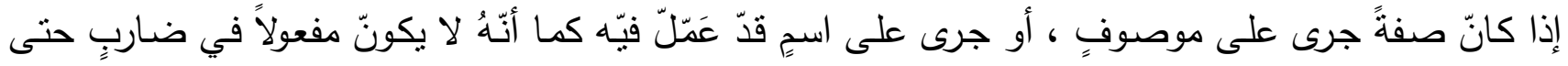

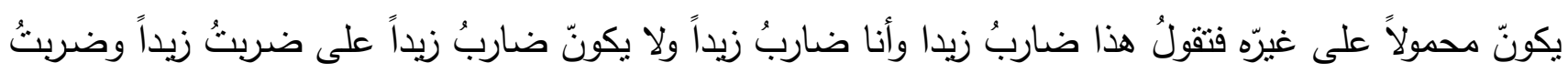

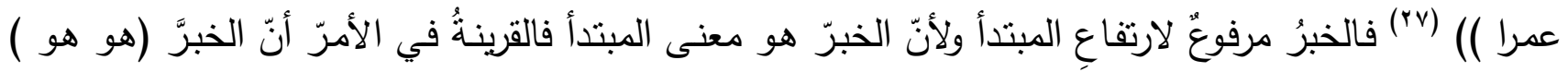

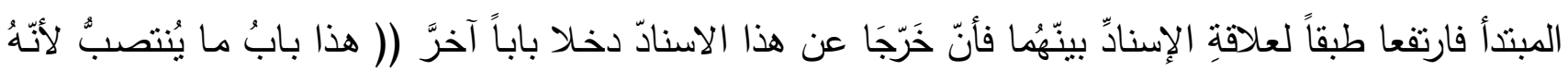

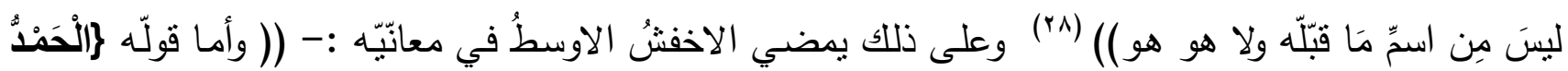

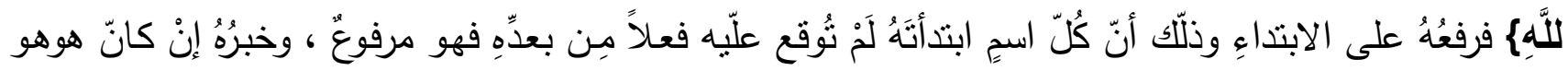

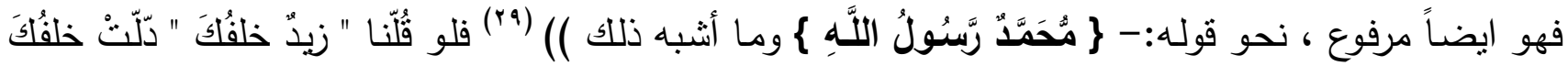

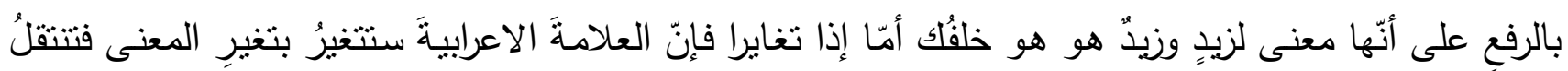

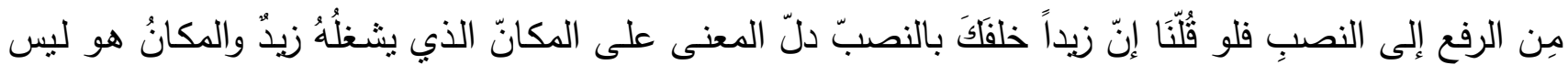

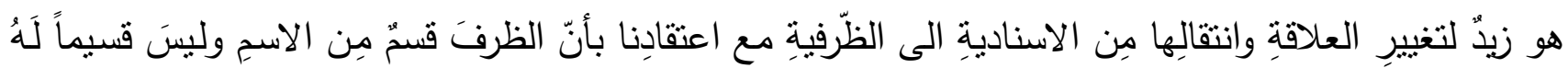

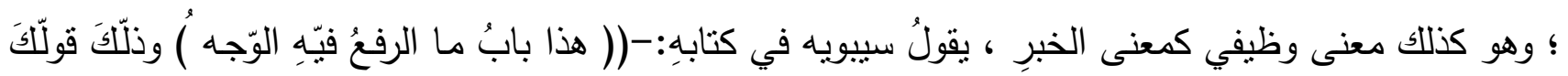

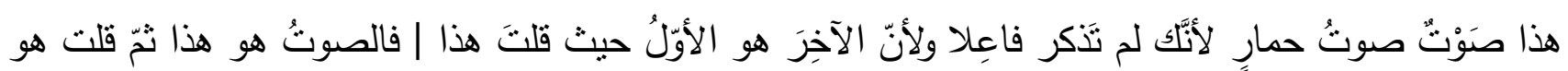

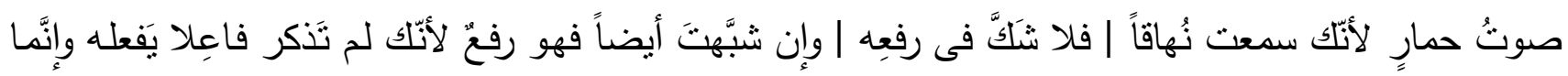

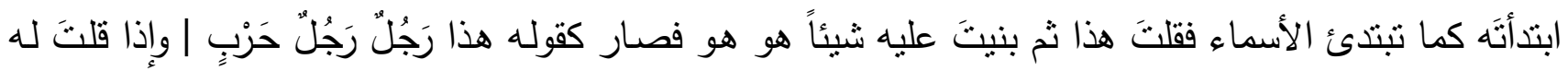

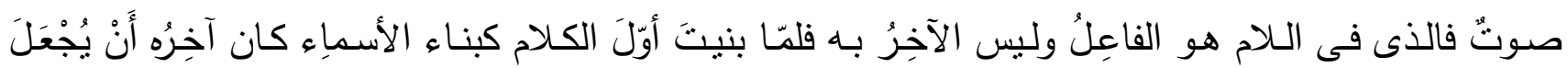

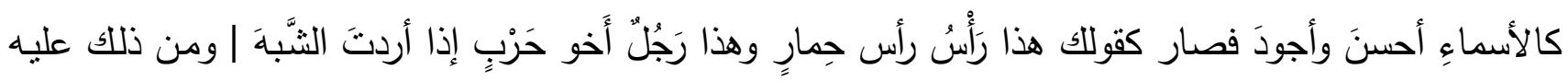

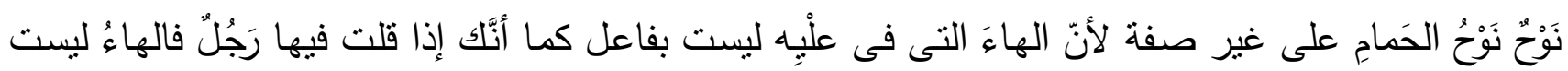

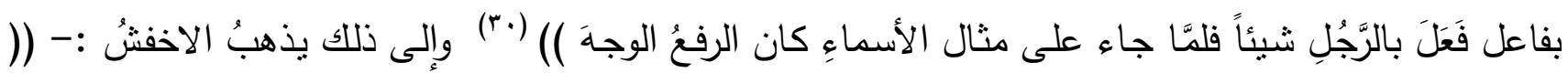

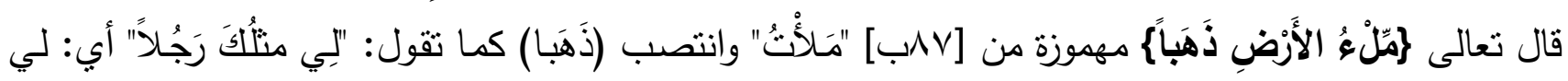


منظلك من الرجال، وذلك لأنك شغلت الاضافة بالاسم الذي دون "الذهب" وهو "الأرض" ثم جاء "الذهب" وهو

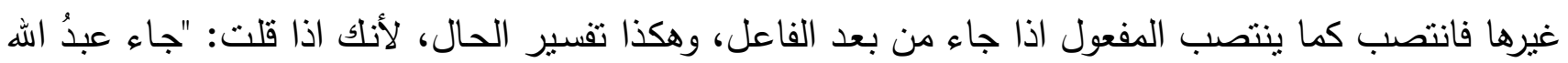

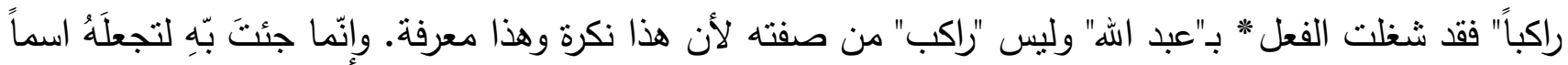

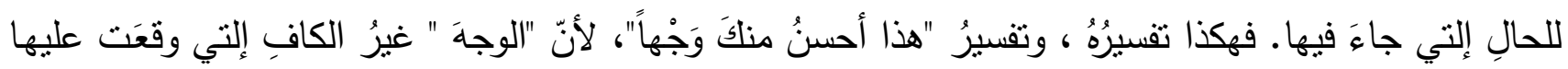

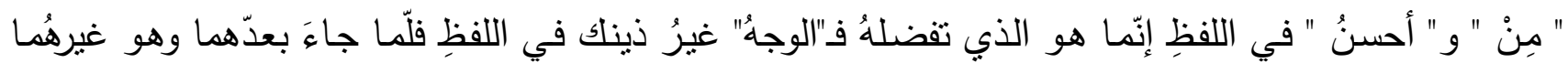

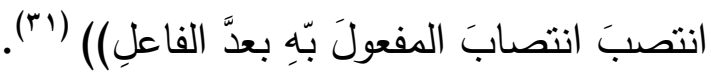

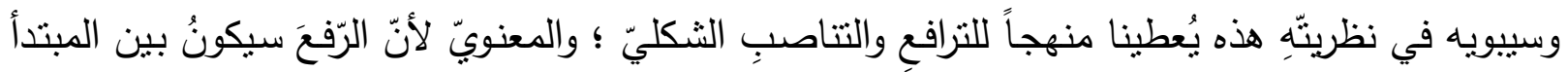

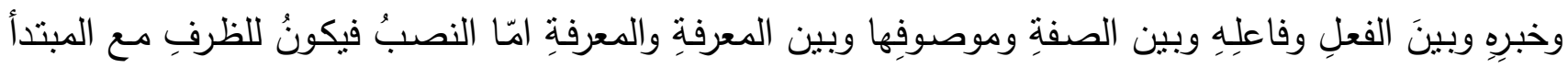

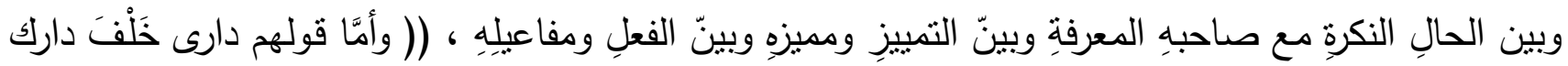

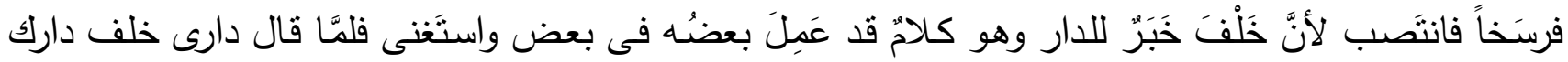

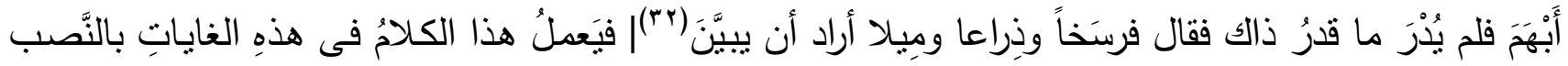

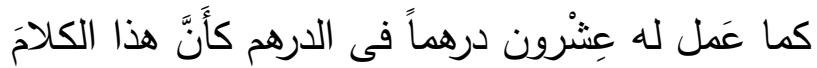

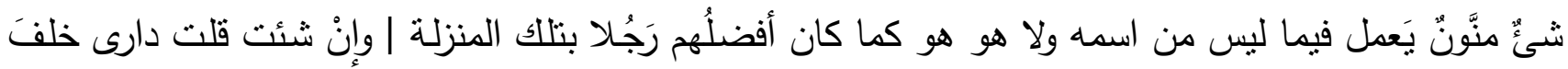

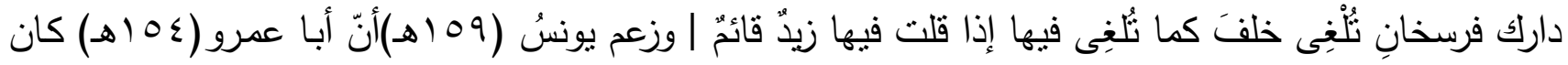

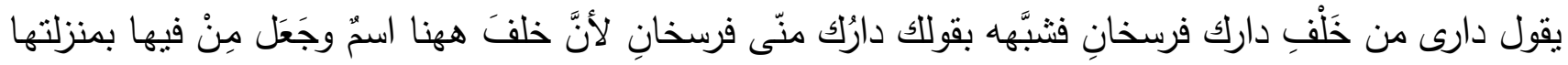

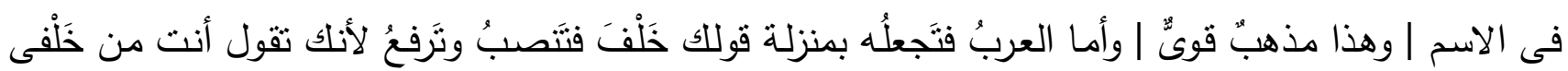

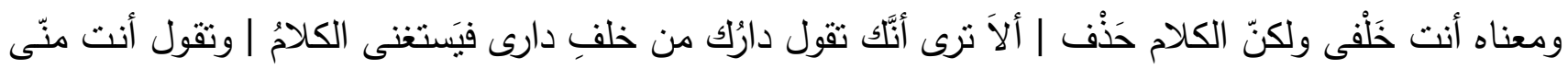

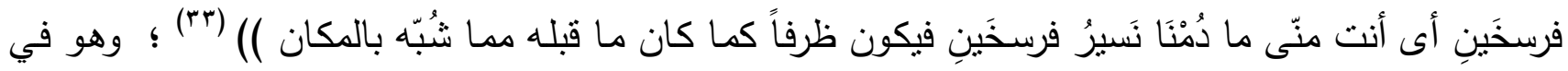

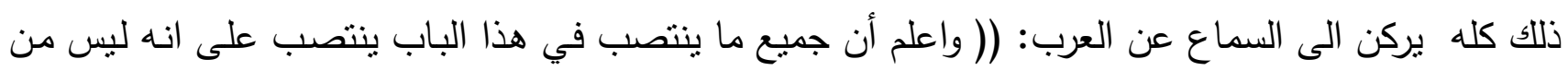

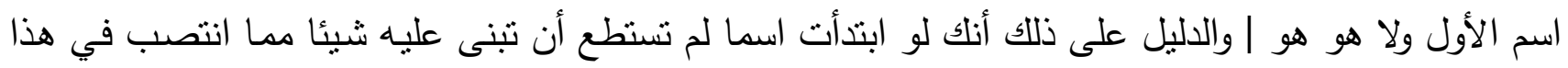

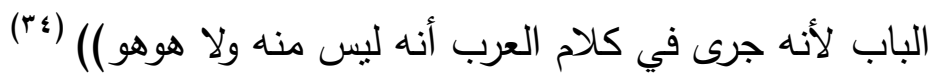

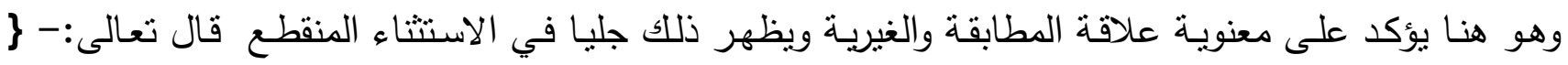

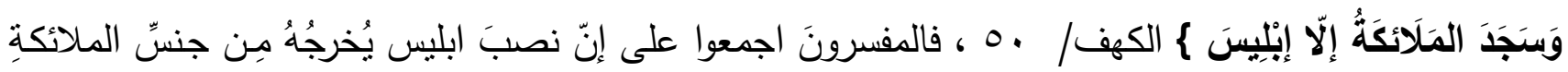




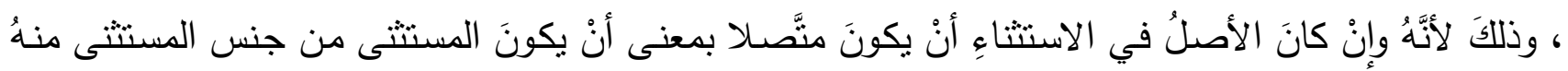

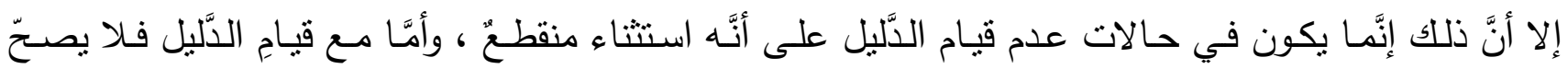

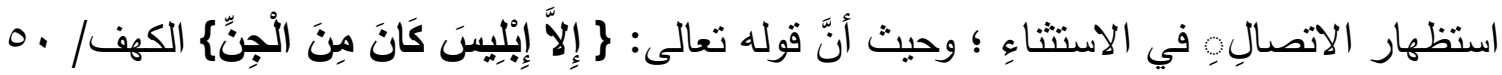

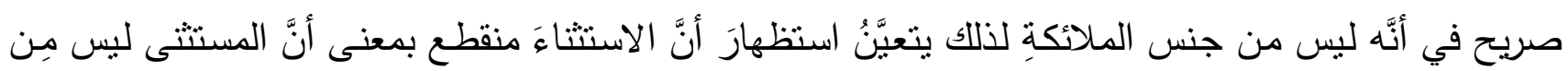

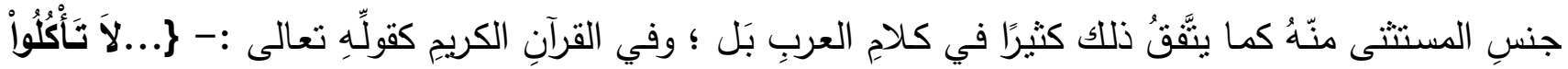

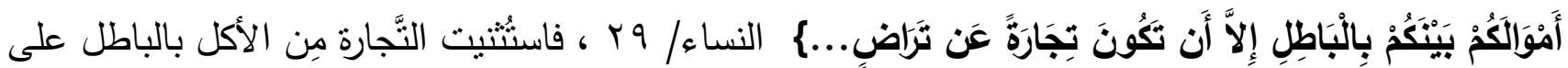

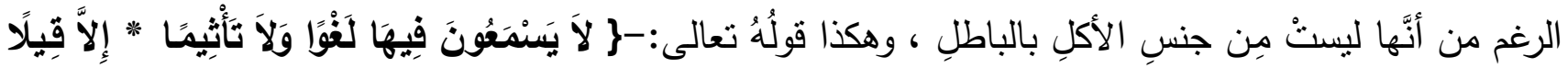

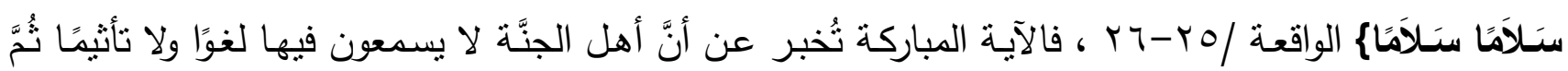

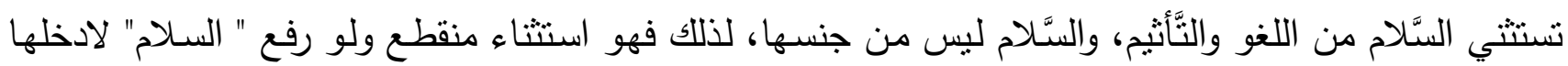

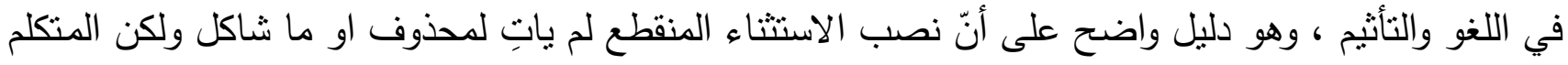

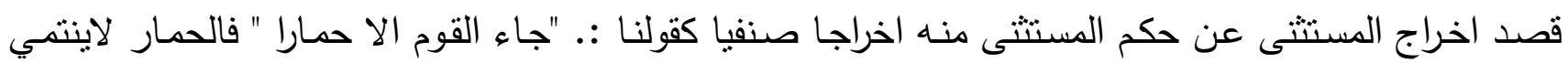

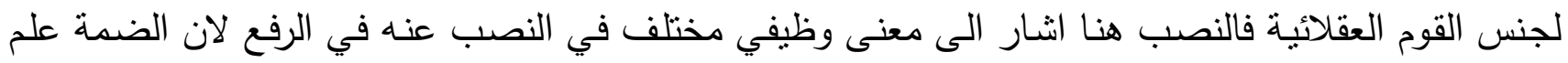

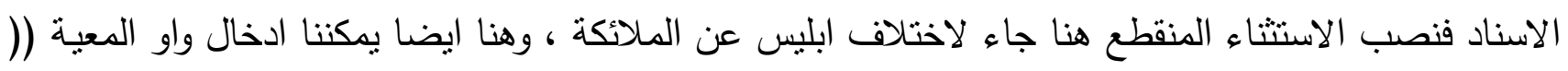

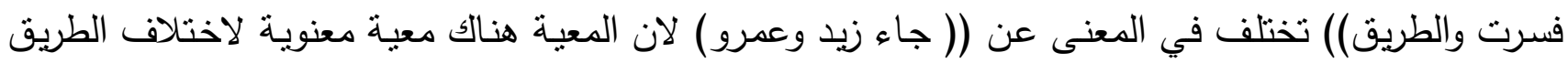

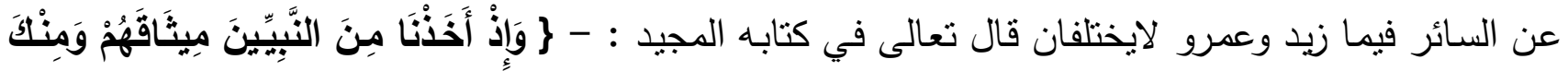

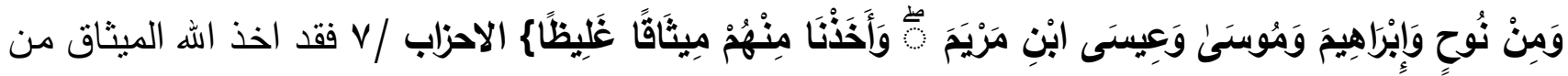
النبين ومن نبينا عليه وعلى اله افصل الصلاة والتسليم ومن نوح وابراهيم فكلهم انبياء متعاطفون ، وقال تعالى :-

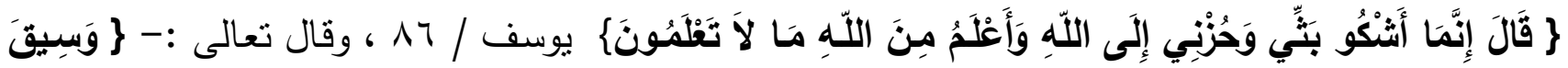

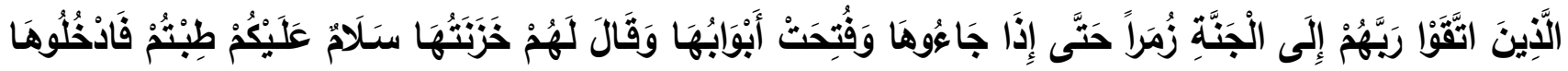

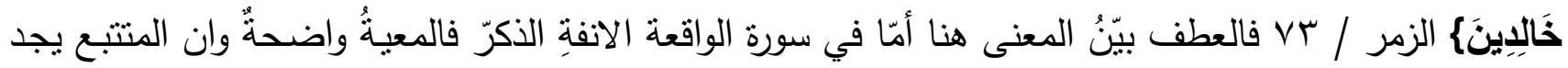

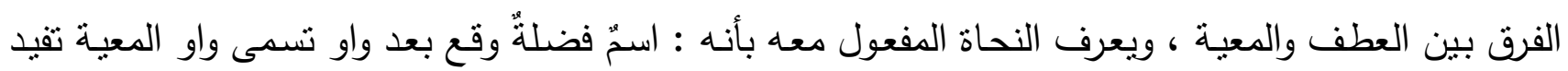

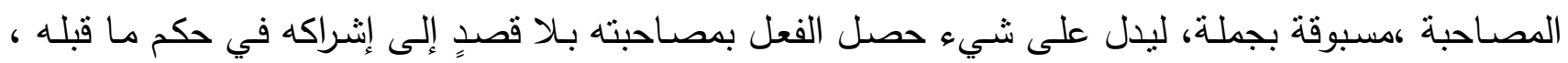

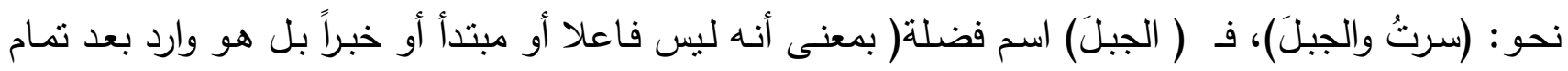


الإسناد)، وقد سبق بجملة من الفعل والفاعل ، ليدلّ على أن السيرَ وَقعَ مصاحباً للجبلِ ، ولو راجعنا شروطَ

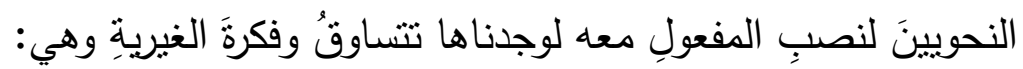

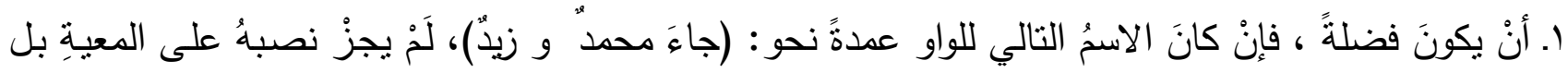

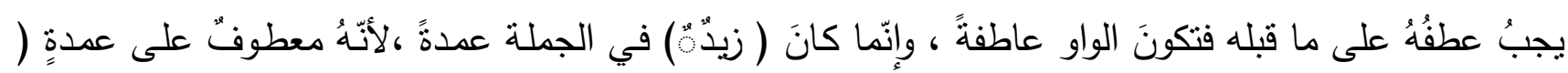

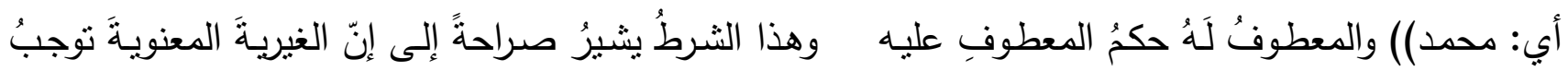

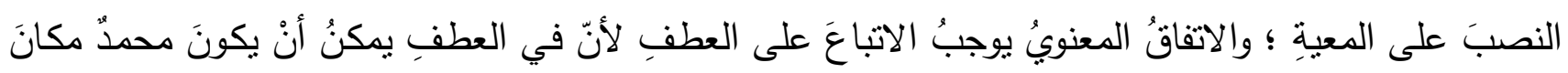

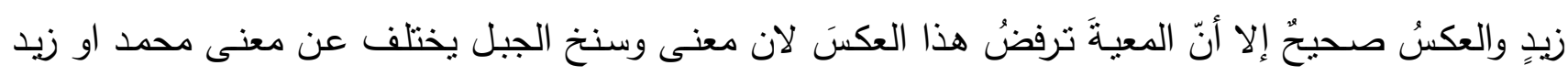
• الادميين

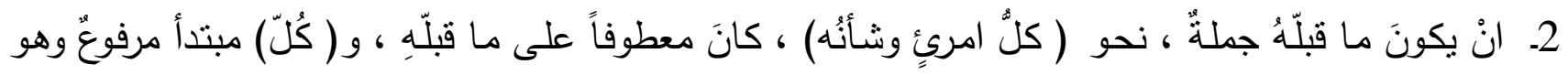

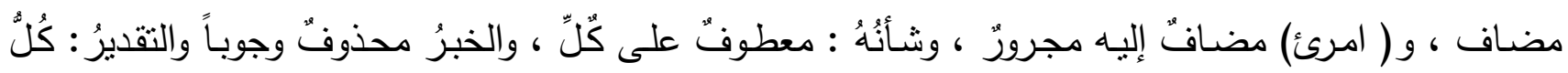

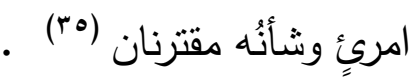

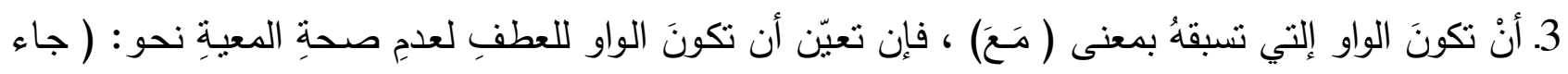

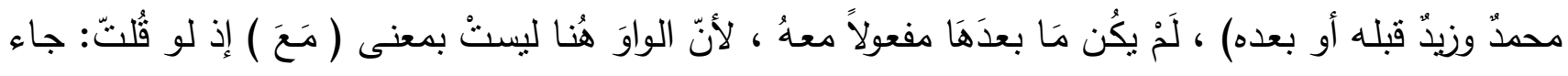

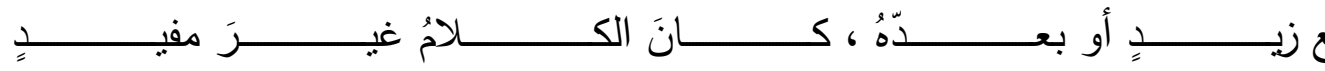

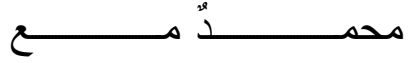

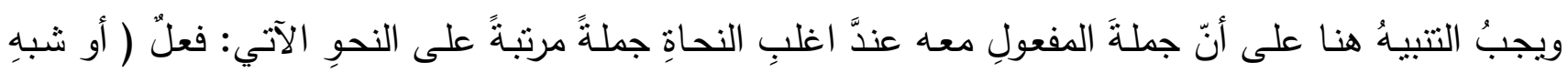

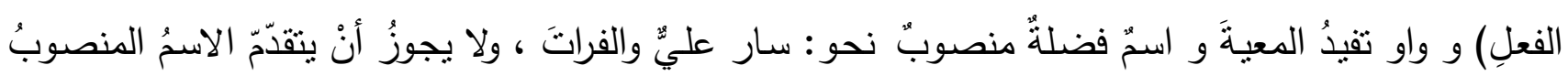

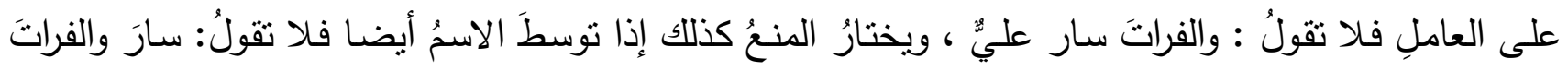

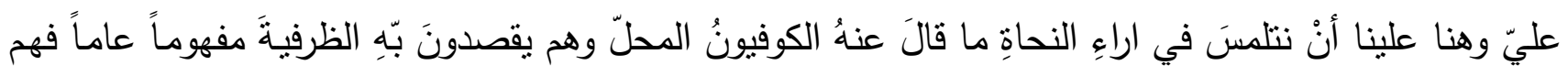

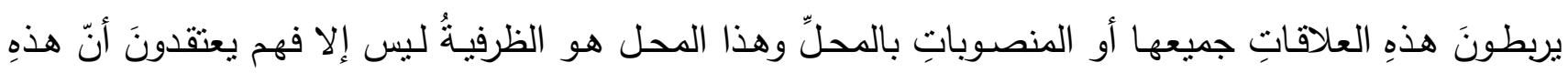

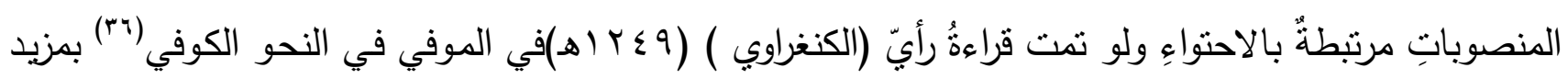

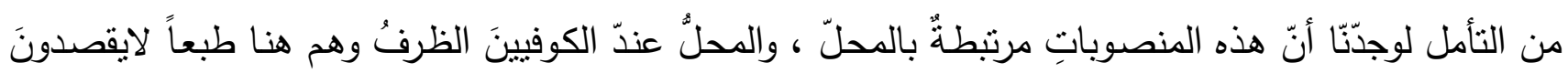

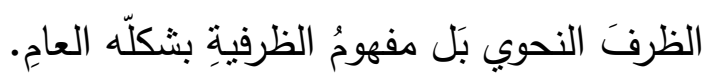
رأيُّ النحاةِ في العاملِ في المفعولِ معه:- 


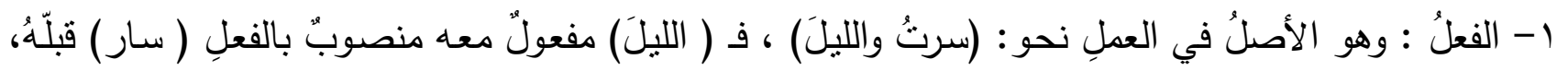

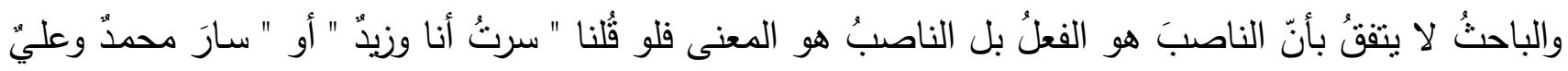

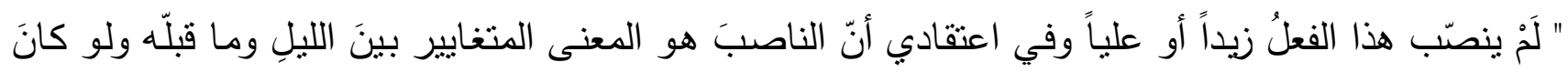
الفعلُ لنصبَ زيداً كما نصبَ الليلَ.

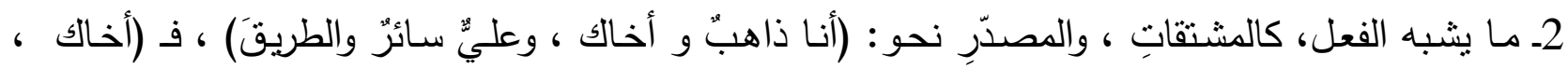

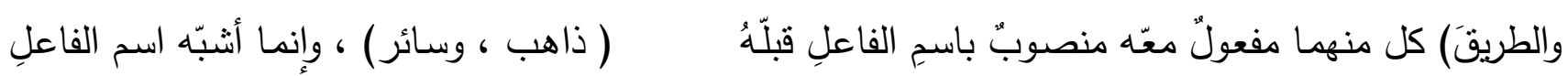

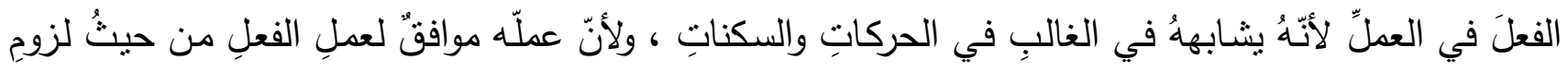

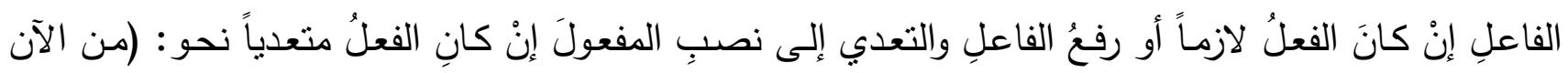

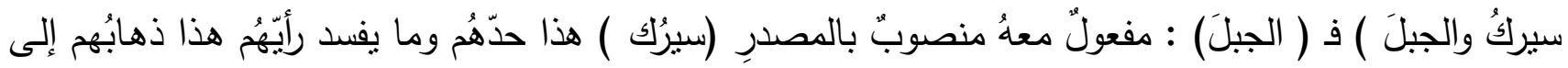

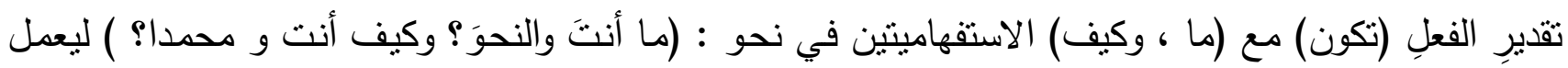

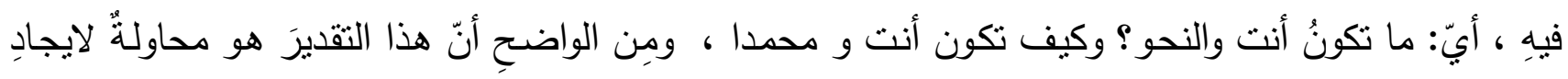

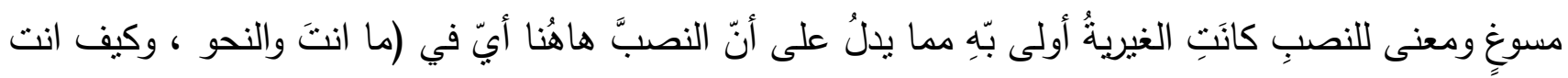

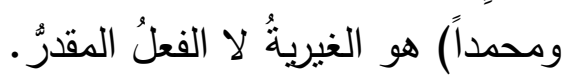

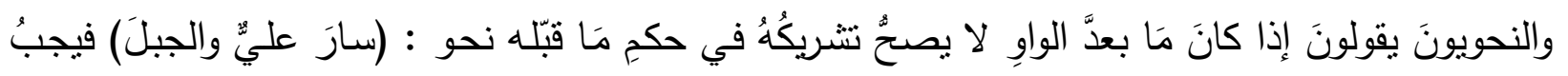

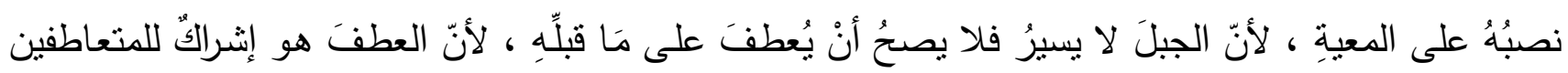

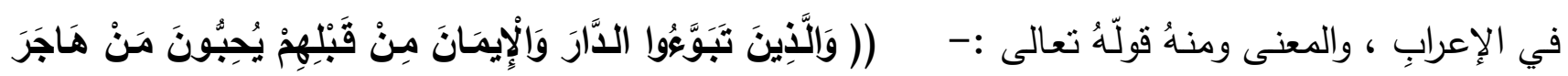

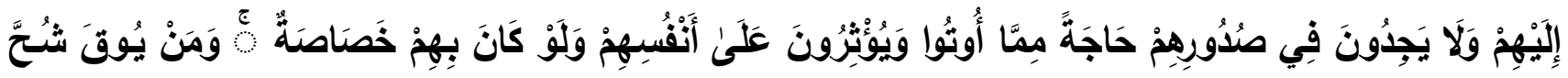

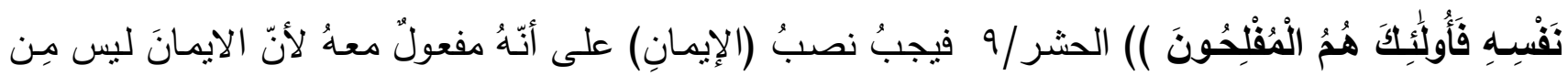

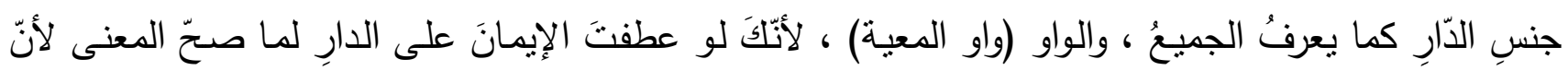

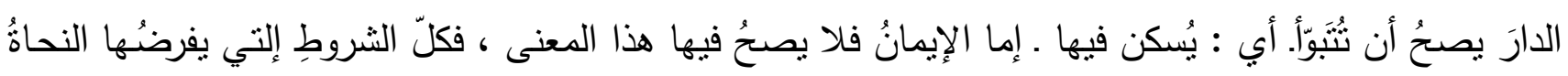

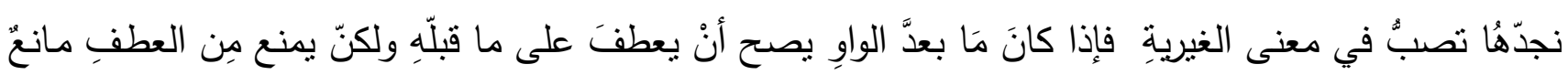

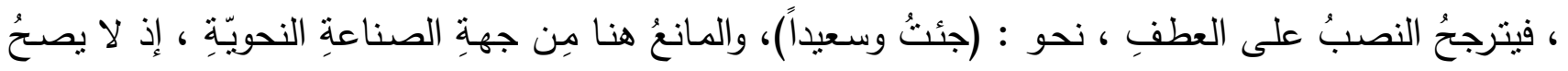

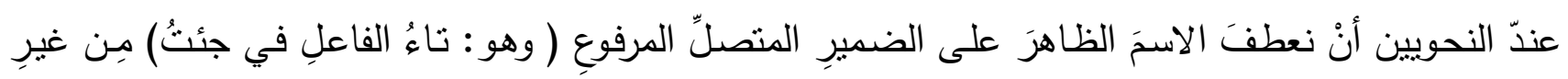




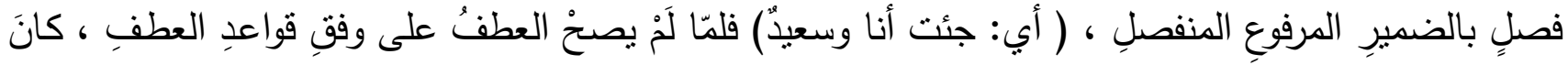

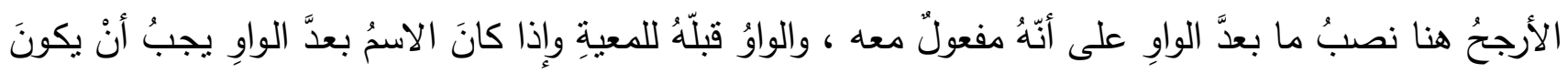

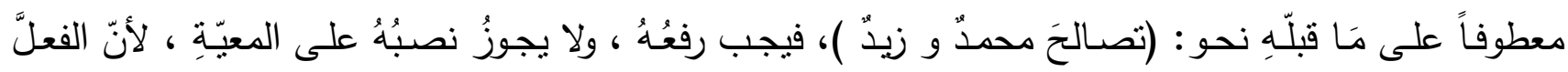

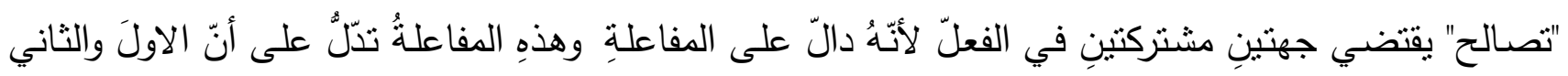

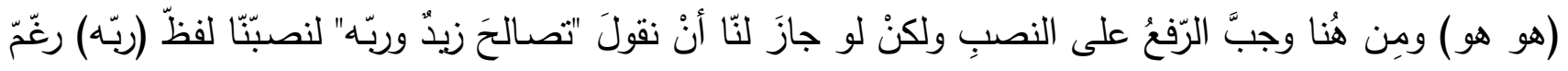

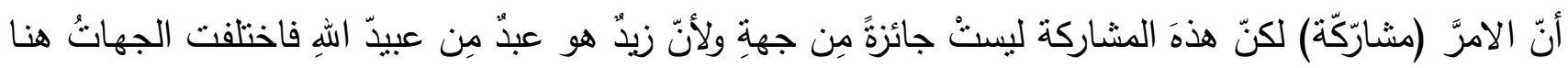

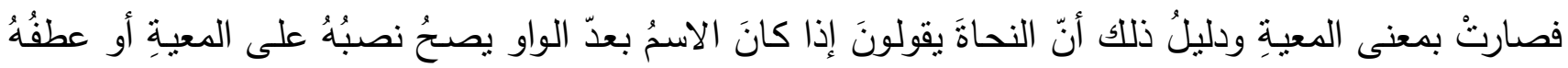

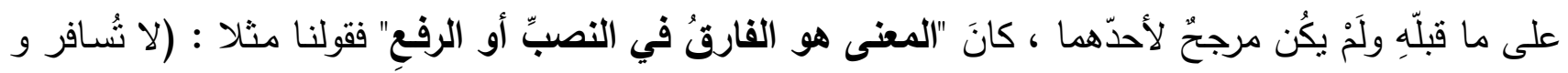

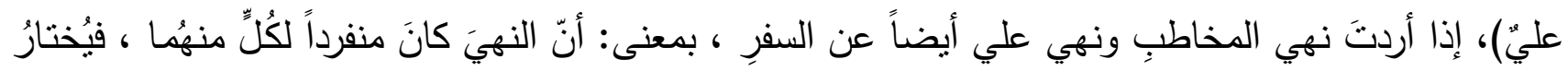

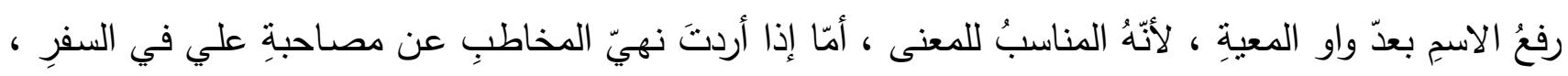

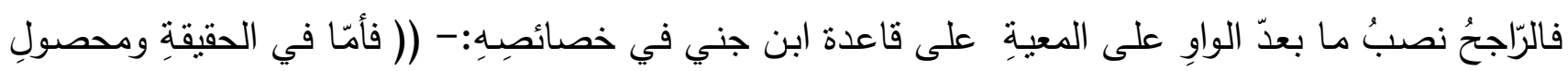

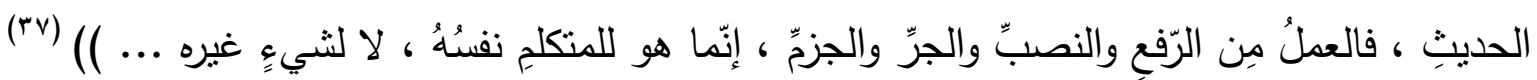

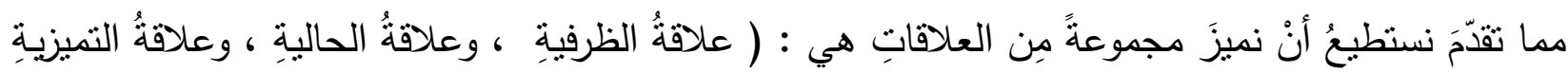

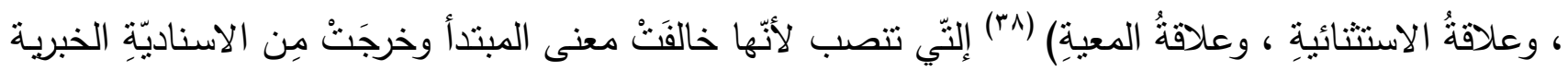

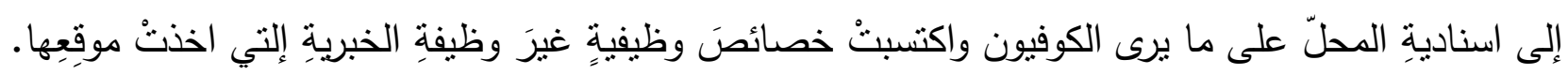

\section{اهم نتائج البحث : -}

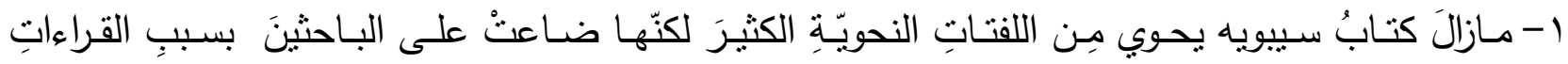

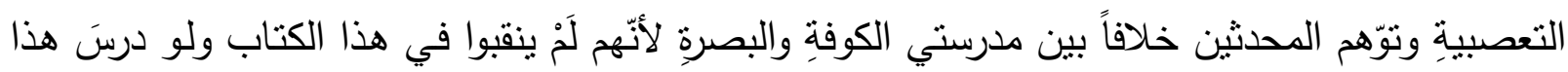

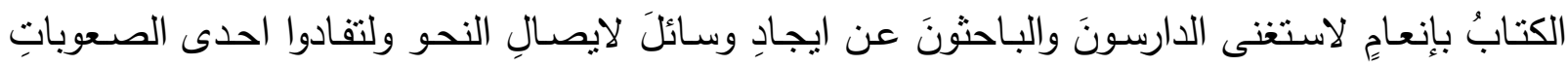

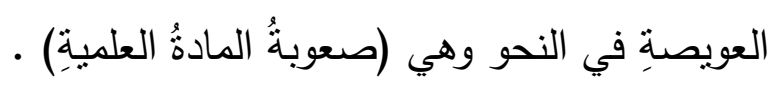

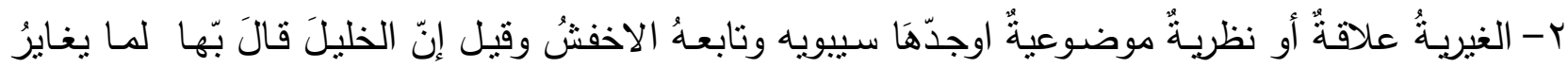
المبتدأ وهذه العلاقةُ يسميها سيبويه (هو هو ) و (هو ليس هو الئه ) وهي مرنبطة بالاسنادِ. 


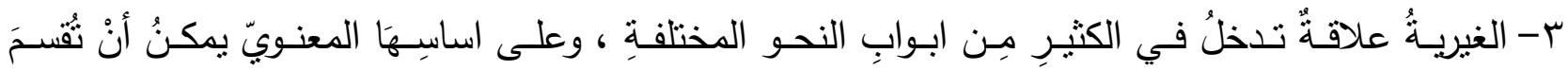

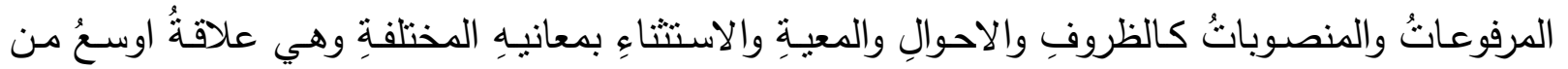
المبتدأ والخبرِ ومرتبطة بالاسناد.

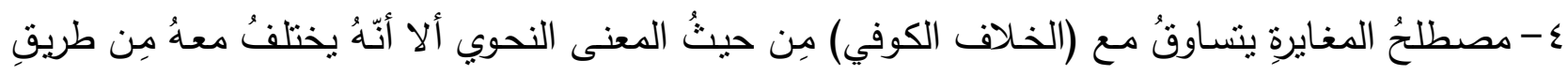

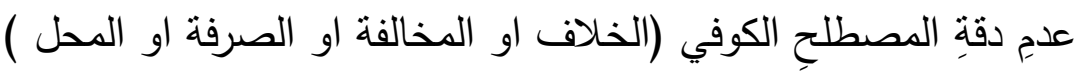

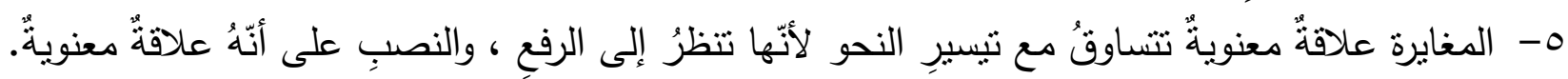

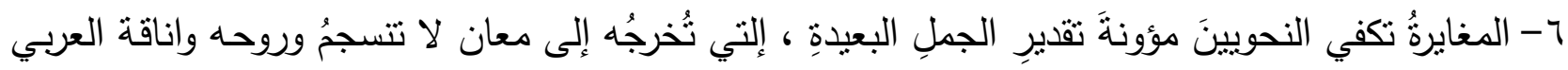

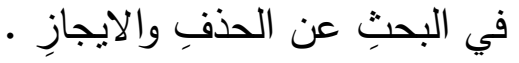

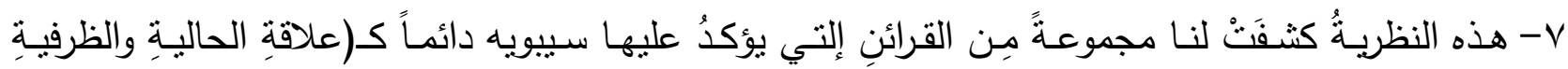
والاستثنائيةِ والمعيةِ وربما التمييزية).

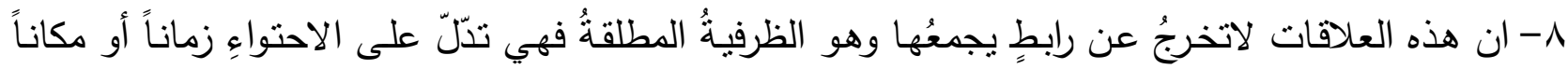

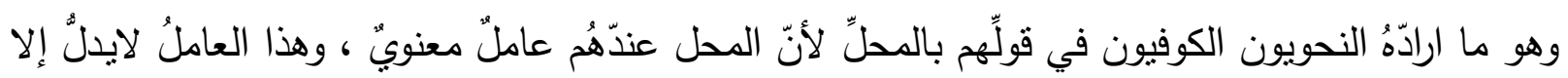

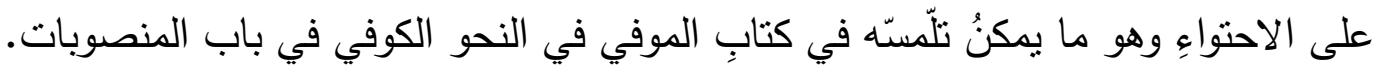


الهوامش والتعليقات

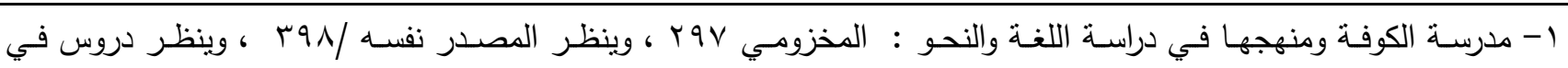

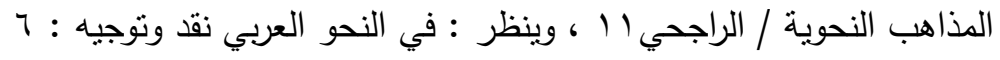

r- ينظر في حركة تجديد النحو وتيسيره في العصر الحديث: 9

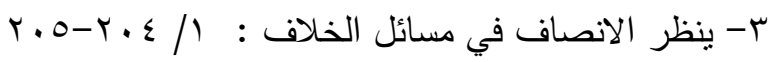

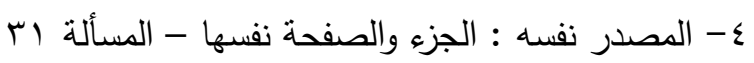

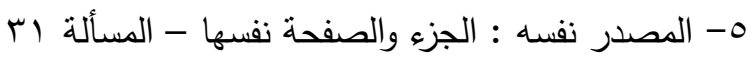

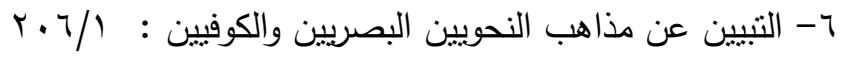

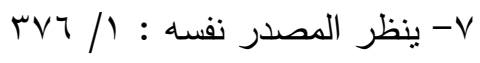

1- الخصائص : 11-11-11

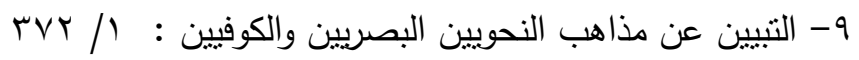

• ا- المصدر نفسه : الصفحة نفسها

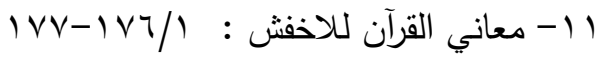

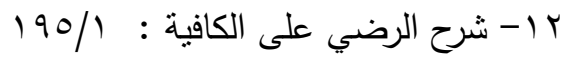

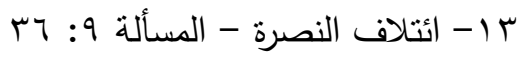

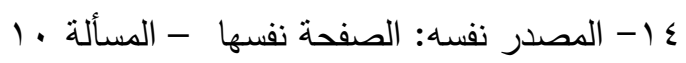

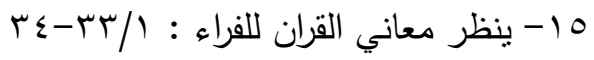

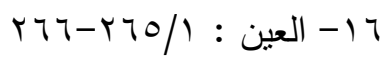

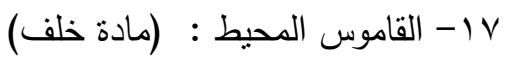

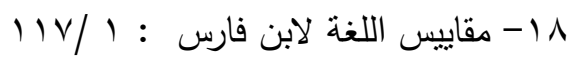

rq 19

•r - المصدر نفسه : وب و ومابعدها ، وينظر النهاية في غريب الحديث والاثر : المجلد الثاني باب الخاء مع اللام ، والمجلد

الثالث باب الغين مع الراء

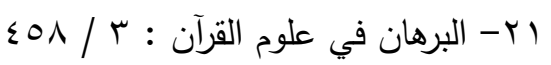

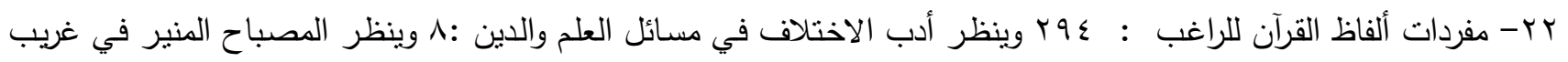

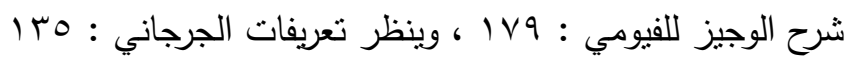




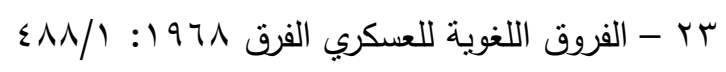

乏

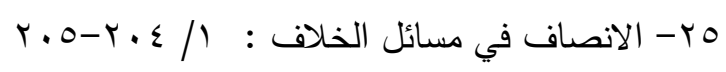

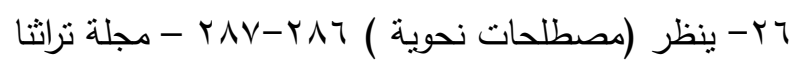

$111 / r:$ : الكتاب

^ץ- المصدر نفسه : الصفحة نفسها ، وينظر الموفي في النحو الكوفي : YVY ومابعدها

$$
\begin{aligned}
& \text { q - معاني القرآن للاخفش : T/1) } \\
& \text {. }
\end{aligned}
$$

| IVV-IVT/L : : معاني القرآن للاخفش

rr- التمييز تفسير او تبيين في كتاب سيبويه - مصطلحات نحوية

كוr

ع

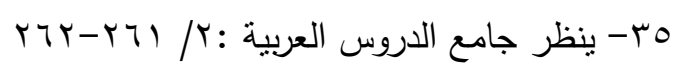

بr- ينظر الموفي في النحو الكوفي : بVY وما بعدها

V

مr مب ينظر الموفي في النحو الكوفي :

\section{المصادر والمراجع \\ أ - القرآن الكريم \\ ب - المصادر العربية}

ا - ائتلاف النصرة في اختلاف نحاة الكوفة والبصرة - عبد اللطيف بن ابي بكر الثَرجّي الزبيدي -تحقيق طارق الجنابي

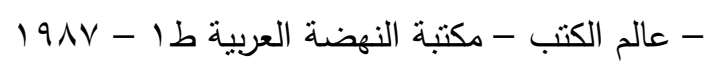

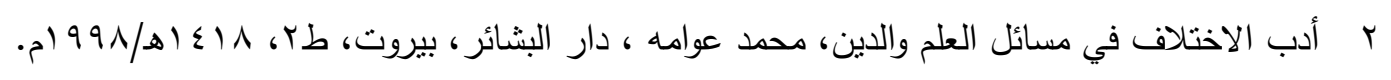

ب الإيضاح في علل النحو : أبو القاسم عبد الرحمن بن إسحاق الزجاج ، ، تحقيق مازن المبارك ، دار النفائس ، بيروت

$$
\text { rba pla19، }
$$


ع البرهان في علوم القرآن : بدر الدين الزركثي تحقيق محمد أبو الفضل إبراهيم : دار التراث / ·99 ام

ه التبين عن مذاهب النحويين البصريين والكوفيين ابي البقاء الكعبري تحقيق ودارسة عبد الرحمن بن سليمان العثيميين -

$$
\text { دار الغرب الاسلامي - بيروت / لبنان طا 919 ام }
$$

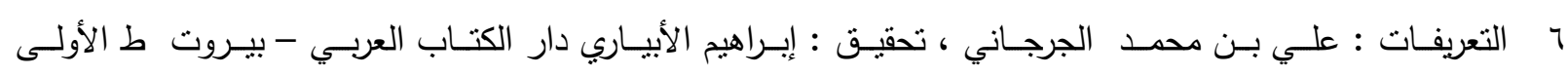

$$
.01997 / 81 \leqslant 17
$$

V جامع الدروس العربية : الثيخ مصطفى غلاييني / المكتبة العصرية كبيروت ، صيدا ط مب لسنة ب99 ام ^ الخصائص : ابن جني ، أبو الفتح عثمان ، ، تحقيق محمد علي النجار ، دار عالم الكتب ، بيروت ، 7 . . ب مـ ل 1427هـ ، ط ا

$$
\begin{aligned}
& 9 \text { دروس في المذاهب النحوية: عبده الراجحي- دار النهضة العربية - بيروت - . } 191 \\
& \text { • } 1 \text { الرد على النحاة:ابن مضاء القرطبي حقيق شوقي ضيف،دار المعارف،بر919 م ، ط r }
\end{aligned}
$$

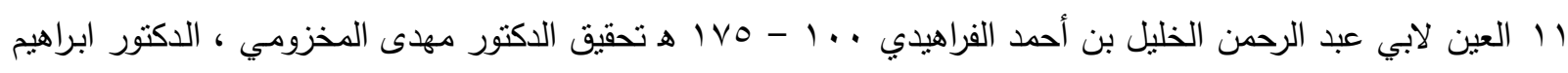

$$
\text { r السامرائي الجزء الرابع مؤسسة دار الهجرة }
$$

با في النحو العربي نقد وتوجيه : مهدي المخزومي : دار الرائد العربي - بيروت طץ / 1919

ـ ا في حركة تجديد النحو وتيسيره في العصر الحديث : نعمة رحيم العزاوي ، بغداد /9900م

$$
10 \text { القاموس المحيط مجد الدين محمد بن يعقوب الفيروزآبادي - دار الجيل }
$$

17 


\section{العدد الرابع عشر}

1919 منهج كتاب سييويه في التقويم النحوي : محمد كاظم البكاء بغداد: دار الثنؤون الثقافية العامة، 11 الكتاب : عمرو بن عثمان بن قَنْبر ، الملقب بـ سييويه : تحقيق: عبد السـلام محمد هارون الهيئة المصرية العامة

$$
\text { للكتاب }
$$

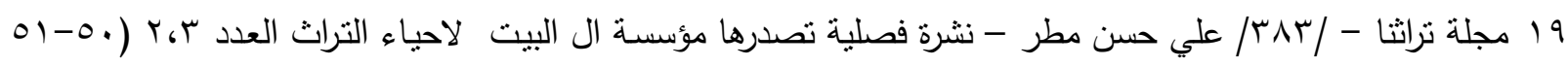

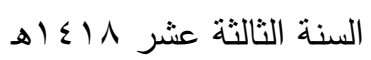

• r النهاية في غريب الحديث والاثر : فخر الدين بن الأثثر ، تحقيق عبد الحميد هنداوي : المكتبة العصرية للطباعة

$$
\text { والنشر/ طا }
$$

ا ب شرح الرضي لكافية ابن الحاجب : محمد بن الحسن الإستراباذي الرضي تحقيق وتصحيح وتعليق: أ. د. يوسف حسن

$$
\text { عمر ط: 19v0 19 مامعة قار يونس - ليبيا }
$$

r ب معجم المصطلحات النحوية والصرفية : محمد سمير نجيب اللبدي ، مؤسسة الرسالة - دار الفرقان / 1910 r ب معاني القرآن : الإمام أبو زكريا يحيى بن زياد الفراء المتوفى سنة V.r هـ : دار عالم الكتب الطبعة : الثالثة لسنة

$$
\text { b) }
$$

צr معاني القرأن : أبو الحسن المعروف بالأخفش الأوسط ته آهـ تحقيق: هدى محمود قراعة / مكتبة الخانجي، القاهرة

$$
\text { الطبعة :الأولى . } 199
$$

O T المصباح المنير في غريب شرح الوجيز: أحمد بن محمد الفيومي ، المكتبة العلمية ، بيروت. جr مدرسة الكوفة ومنهجها في دراسة اللغة والنحو : مهدي المخزومي طب -1901 شركة ومطبعة ومكتبة البابي الحلبي

$$
\text { واولاده بمصر . }
$$

م rV مفردات الفاظ القرآن للراغب الأصفهاني ، طr، دار القلم، دمشق، سنة / 999 م ـ 
^ץ معجم مقاييس اللغة : أحمد بن فارس بن زكريا أبو الحسين : تحقيق عبد السلام محمد هارون ، دار الفكر ، بيروت /

qr الموفي في النحو الكوفي : صدر الدين الكنغراوي : تحقيق: محمد بهجة البيطار / دار النوادر للنشر والتوزيع طا. 